\title{
Suriye İç Savaşı ve Türkiye: Çatışma, Güvenlik ve Siğınma
}

DOI: $10.26466 /$ opus.714551

*

\section{İ. Aytaç Kadıŏ̆lu *}

* Dr. Öğr. Üyesi, Adıyaman Üniversitesi, İktisadi ve İdari Bilimler Fakültesi, Adıyaman/Türkiye E-Posta: akadioglu@adiyaman.edu.tr

ORCID: $\underline{0000-0001-7957-0900}$

\section{Öz}

Arap Baharı ayaklanmalarının başlangıcından kısa süre sonra Suriye'ye sıçrayan protestolar, Suriye rejiminin göstericilere şiddet uygulamasıyla tüm ülkeyi saran bir iç savaşa dönüşmüştür. 2011 yılında başlayan iç savaş yüzbinlerce insanın hayatını kaybetmesine neden olmuş, bunun yanında politik, ekonomik, sosyo-kültürel ve güvenlik alanlarnda pek çok bölgesel problemi de beraberinde getirmiştir. Türkiye Suriye'deki iç savaştan en çok etkilenen ülkelerden biridir. DEAŞ (Irak ve Şam Devleti) ve PYD/YPG (Demokratik Birlik Partisi/Halk Savunma Birlikleri) gibi terör örgütlerinin varlığı, ABD ve Rusya'nın bölge üzerindeki hâkimiyet amacı, Ortadoğu'daki bölgesel güçlerin çıkarları gibi konular Türkiye'nin güvenliğini git gide artan oranda tehdit etmektedir. Ancak, iç savaşın Türkiye'nin güvenliğine etkisi akademik literatürde yeterli düzeyde analiz edilmemiştir. Literatürdeki bu boşluğu doldurmak için bu makale, Türkiye'nin güvenliği sorununu iki temel faktör bağlaminda analiz etmektedir: yaylma etkisi ve sığınmacılar sorunu. Bu makalede birincil kaynak olarak Türkiye, ABD ve İngiltere tarafindan yayınlanan resmi raporlar kullanılmaktadır. Bu kaynaklardan elde edilen veriler Türkiye'nin resmi yetkililerinin Türkiye'nin Suriye iç savaşı bağlamındaki açıklamalarıla zenginleştirilecektir. Bu makale, Türkiye'nin Suriye'deki iç savaştan yayılma etkisi bağlamında ağır biçimde etkilendiği, ancak Suriyeli sığınmacıların güvenlik anlamında bugüne kadar büyük bir tehdit oluşturmadığı sonucuna varmıştır.

Anahtar Kelimeler: Suriye iç savaşı, Türkiye'nin güvenlik politikası, yayılma etkisi, sığınmacılar, sinır güvenliği. 


\title{
The Syrian Civil War and Turkey: Conflict, Security and Refugees
}

\begin{abstract}
The Arab uprising protests spread into Syria after a short time, which turned into a civil war when the Syrian government attacked protesters. The civil war caused hundreds of thousands of people's lives since its initiation in 2011 and brought about political, economic, socio-cultural and security issues. Turkey has been one of the most affected countries of the war in Syria. DAESH (Islamic State in Iraq and Syria) and PYD/YPG (Democratic Union Party/People's Defence Units) terrorist organisations, the US and Russia's rivalry to take the region under control, the competing interests of the regional powers of the Middle East posed security threats for Turkey. However, this issue has not been sufficiently assessed in the existing scholarly literature. In order to fill this gap, the article offers a bilateral analysis to understand Turkey's security concerns: the spillover effect and the issue of refugees. This article uses official reports published by the Turkish and British governments and the US administration as primary sources. These sources are complemented through the speeches of Turkish officials to comprehend Turkey's security perception in regard to the Syrian civil war. The article claims that the Syrian civil war has caused a threat towards Turkey's security through the attacks of the terrorist organisations. However, the article has found that Syrian refugees have not caused any major security issues since the beginning of the conflict.
\end{abstract}

Keywords: Syrian civil war, Turkey's security policy, spillover effect, refugees, border security 


\section{Giriş}

Suriye'de Mart 2011'de başlayan barışçl protestolar kişi hak ve özgürlüklerinin tanınması, yolsuzluğun ortadan kaldırılması, yüksek işsizlik oranlarının düşürülmesi, halkın Suriye Devlet Başkanı Beşar Esed yönetiminden memnun olmaması ve demokratik yönetim talepleriyle başlamış ve kısa sürede Suriye'nin geneline yayılmıştır. ${ }^{1}$ Ortadoğu ve Kuzey Afrika ülkelerinin geneline yayılan bu protesto eylemleri bazı ülkelerde siyasi ve ekonomik reformlarla sonuçlanmış, bazılarında ise eylemcilerin rejimin sona ermesi ve daha demokratik bir siyasi sistemin getirilmesi yönündeki talepleri ve baskıları otoriter rejimlerin yıkılmasına neden olmuştur. Suriye'de ise iktidardaki Baas partisinin baskıcı yönetimine yönelik barışçıl protestolar Esed yönetiminin direktifleriyle Suriye ordusunun göstericilere ateş açması sonucu şiddet eylemlerine dönüşmüştür. Bu baskılar sonucu, Suriye'nin her bölgesinde muhalif gruplar Esed yönetimine karşı örgütlenmiş ve çatışmalar kısa sürede iç savaş halini almıştır.

Savaşın şiddetinin artması Suriye ile 911 km'lik sınıra sahip olan Türkiye'nin, git gide daha fazla oranda zarar görmesine yol açmıştır. DEAŞ² terör örgütüne karşı Amerika'nın başını çektiği Batı koalisyonu (Koalisyon güçleri) ile ortak operasyon yapan Türkiye, bu terör örgütünün hedefi haline gelmiş ve yüzlerce kişi DEAŞ’ın terör saldırıları sonucu hayatını kaybetmiştir. Bundan sonraki dönemde küresel ve bölgesel güçlerin ortak hareket etmesiyle DEAŞ’ın etkisi azalmıştır. Ancak, DEAŞ’a karşı kurulan koalisyonda desteklenen diğer devlet dışı örgütler Suriye'de toprak iddiasında bulunmuştur. Bu durum, Türkiye sınırında bir PYD/YPG terör devleti kurulacağına yönelik endişeleri kuvvetlendirirken, Türkiye Suriye'deki vekâletler savaşında

\footnotetext{
${ }^{1}$ Suriye devlet başkanı 2000 yılında iktidara geldiğinden 2011 yılına kadar Türkiye'de Beşar Esad olarak anılmış, Arap Baharı ayaklanmalarının başlamasıyla birlikte Beşar Esed olarak kullanılmışır. ikisi de Arapça olan kelimelerden 'esad' en bahtiyar, 'esed' ise aslan anlamına gelmektedir. iki kullanım arasında herhangi bir ideolojik ayrım, övme ya da yerme durumu söz konusu değildir. Arap ülkelerinde ise yaygın kullanım 'Esed' şeklindedir. Dolayısıyla, bu makalede literatürdeki yaygın kullanım tercih edilmistir.

${ }^{2}$ Terör örgütü Dawlah al-Islamiyah fil-'Iraq wa ash-Sham (DAESH) ismi Arapça karşılığı iken, Avrupa devletleri genelde DAESH şeklinde, ABD ise ISIL-ISIS-IS (Islamic State of Iraq and the Levant-Islamic State of Iraq and Syria-Islamic State) kısaltmalarını kulanmaktadır. Türkiye'de daha önce kullanılan IşiD tabiri ise Türkçe Irak Şam İslam Devleti'nin bir kısaltmasıdır. 2016 yılından itibaren terör örgütü Avrupa kullanımına uygun şekilde DAEŞ ve DEAŞ şeklinde kullanılmaya başlanmış, son dönemde ise genel kullanım şekli DEAŞ şeklindedir. Bu makale, anlatımda isim karmaşasını ortadan kaldırmak için DEAŞ kısaltmasını kullanmaktadir.
} 
PYD/YPG'ye karşı mücadele eden Özgür Suriye Ordusu'nu (ÖSO) desteklemiştir. ABD ve Rusya'nın başını çektikleri Batı ve Doğu koalisyonu, savaş boyunca çatışan çıkarlarını gerçekleştirmek için savaşan taraflara diplomatik baskı yaparak barışı sağlamak yerine çatışmayı şiddetlendirici rol oynamıştır. Türkiye savaşın şiddetinden en çok etkilenen ülkelerden biri olmuştur. Bunun yanında, savaştan kaçan sivillerin ilk sığındığı duraklardan birisi de yine Türkiye olmuş, 19 Mart 2020 itibariyle ülkedeki Suriyeli sayısı resmi rakamlara göre 3.587.779'dur (GİGM, 2020). Bu makale, Suriye iç savaşının Türkiye üzerindeki etkisini anlamak için 'Suriye iç savaşı Türkiye'nin güvenliğini ne derece etkilemiştir?' sorusunu sormaktadır. Bu soruya cevap verebilmek için bu makale ikili bir analiz yapmaktadır: yayılma etkisi ve sığınmacılar sorunu. Bu çalışmada, savaştan kaçan sığınmacıların çok büyük bir kısmının şiddet eylemleriyle herhangi bir ilişkisi olmadığı gerçeğinden hareket etmektedir. Bunun yanında, sığınmacıların yaşama hakkı çerçevesinde ülkelerinden ayrılmak zorunda kaldıkları ve daha iyi koşullarda yaşamak için öncelikli olarak ve gerekli bir biçimde komşu ülkelere sığındıkları göz önüne alınmaktadır. Bu durumun, sığınmacılık ve mülteciliğin güvenlik probleminde bir kaynak oluşturması ise sığınmacılığın genel değil, potansiyel sonuçlarından biri olarak değerlendirilebilir ve mültecilerin çoğunluğunun herhangi bir silahlı eyleme katılmadıkları gerçeğini değiştirmez.

Makale, bu araştırma sorusuna cevap verebilmek için çeşitli kaynaklardan faydalanmaktadır. Birincil kaynak olarak ABD, İngiltere ve Türkiye resmi makamları tarafından yayınlanan raporlar ve demeçler kullanılmaktadır. $\mathrm{Bu}$ kaynaklar ulusal ve uluslararası kuruluşlardan elde edilen birincil kaynaklarla doğrulanmaktadır. Bu kaynakların en önemlilerinden biri Birleşmiş Milletler Güvenlik Konseyi'nin (BMGK) alış olduğu kararlardır. Bu sayede kapsamlı ve güvenilir bir analiz yapma imkânına sahip olunacaktır.

Bu araştırma dört bölümden oluşmaktadır. Birinci bölümde Suriye iç savaşının tarihsel arka planı anlatılacaktır. Aynı zamanda Türkiye'nin Suriye iç savaşına ne zaman ve nasıl müdahil olduğu da tartışılacaktır. İkinci bölümde çatışmanın yayılma etkisi ve sığınmacılık sorunlarına ilişkin bir teorik çerçeve çizilecektir. Üçüncü bölümde Suriye iç savaşının Türkiye'nin güvenliğine etkisi analiz edilecektir. Son bölümde ise analiz edilen konulara ilişkin temel sonuçlar ortaya konacaktır. 


\section{Suriye İç Savaşı'nın Tarihsel Arka Planı}

Arap Baharı ayaklanmaları Tunus'ta bir seyyar satıcı olan Muhammed Bouzazi'nin kendisini yakması ile 2010 yılının Aralık ayında başlamıştır. Hükümet karşıtı protestolar Tunus'tan Bahreyn, Libya, Misır, Suriye ve Yemen'e yayılmış, bu ülkelerde rejimlerin yıkılması, ayaklanma, iç savaş ya da etnik ve mezhepsel çatışmalar şeklinde kendini göstermiştir. Cezayir, Fas, Irak, İran, Kuveyt, Lübnan, Sudan ve Ürdün'de ise büyük sokak gösterileri ve şiddet eylemleri yaşanmıştır. Cibuti, Filistin, Moritanya ve Suudi Arabistan'da ise daha düşük şiddetli protestolar görülmüştür. Ayaklanmalar neredeyse bütün Ortadoğu ve Kuzey Afrika bölgesine yayılmıştır. Suriye, Esed rejiminin kendi halkına uyguladığı şiddet ve katliamlar, ülkedeki terör örgütlerinin saldırıları, büyük devletlerin ve bölgesel güçlerin faaliyetleri nedeniyle İkinci Dünya Savaşı sonrası dünyanın yaşadığı en büyük insani kriz bölgesi halini almıştır. İç savaşı özellikler terör örgütlerinin hedefleri, saldırıları ve ortaklıkları üzerinden incelemek Türkiye'nin güvenliğinin nasıl etkilendiğini anlamak için oldukça önemlidir.

Suriye rejiminin sivillere uyguladığ 1 şiddet neticesinde protestoların başladığı günden itibaren yalnızca iki ay içinde binden fazla sivil hayatını kaybetmiştir (Holliday, 2011; Salloum, 2013). Bunun neticesinde Suriye ordusu içinde kopmalar meydana gelmiş ve muhalif askerler ordudan ayrılarak ÖSO'yu kurmuşlardır. İç savaşı sona erdirmeye yönelik çabalar ise savaşın ilk dönemlerinde başlamıştır. İlk barış çalışması Arap Birliği tarafından 2012 yılında gerçekleştirilmiştir. Birliğin aldığı karar ile Suriye'de Arap Birliği İzleme Grubu (Arab League Monitoring Mission) kurulmuş, bu grubun Suriye'deki insan hakları ihlallerini denetleme misyonuna sahip olacağı karara bağlanmıştır (Kadıŏlu, 2020). Ancak, İzleme Grubu başarıya ulaşamamış, Suriye rejimi ile muhalif gruplar arasındaki çatışma daha da şiddetlenmiştir. El-Kaide terör örgütünün Suriye kolu olarak da bilinen el-Nusra Cephesi'nin savaşa dâhil olması çatışmanın seyrini değiştirmiş ve Taffanoz Hava Üssü gibi stratejik konuma sahip üsler el-Nusra tarafından ele geçirilmiştir. PYD/YPG terör örgütünün Suriye'deki diğer terör örgütlerine ve ayrlıkçı grupların Suriye rejimine saldırılar düzenlemesiyle savaş daha da karmaşık bir hal almıştır (van Wilgenburg, 2013). 
2013 yılının Temmuz ayında Suriye'deki diğer silahlı örgütler DEAŞ’a savaş ilan etmiştir. Bu dönemde Suriye rejiminin sivillere yönelik kanlı eylemleri devam etmiş, Suriye ordusunun Halep ve çevre illerde kimyasal silahlarla yapmış olduğu saldırılarda yüzlerce insan hayatını kaybetmiştir (Dagher ve Farnaz, 2013). Ülkedeki otorite boşluğundan faydalanmak isteyen gruplar toprak ele geçirme kaygisıyla birbirlerine savaş ilan etmiştir. Buna en açı örnek PYD/YPG'nin ÖSO ve el-Nusra Cephesi arasında 2013'ün sonlarından itibaren şiddetlenen çatışmalar vardır. DEAŞ Azez, Atme, Rakka, İdlib ve Halep'in bazı bölgeleri gibi stratejik noktaları hızlı bir şekilde ele geçirmiş, muhalif gruplar bu bölgeleri ele geçirmek için DEAŞ’a karşı koalisyon oluşturmuştur. Özellikle Rakka ve Halep iki taraf arasında birçok kez el değiştirmiştir (Lawson, 2014, s.1355). Bu dönem içerisinde terör örgütleri ve muhalif gruplar farklı devletler tarafından vekâletler savaşı yoluyla desteklenmiştir. ABD DEAŞ’la mücadele ve bölgedeki emellerini gerçekleştirebilmek için PYD/YPG terör örgütüne silah, lojistik ve eğitim desteği vermektedir (Cockburn, 2016; Helm, 2014). Rusya ise PYD/YPG'nin bölgedeki saldırılarına göz yumarken, Esed rejimini desteklemektedir. Türkiye ise bölgedeki partneri olarak ÖSO'yu seçmiş ve sınırında PYD/YPG terör örgütünün devlet kurmasını engellemek için önlem almaya çalışmaktadır. Bununla birlikte DEAŞ terör örgütünü ortadan kaldırmak için Türkiye ve ABD ortaklaşa Irak Kürt peşmerge güçlerini eğitmiş ve DEAŞ’a karşı savaşmaları için Türkiye üzerinden Ayn el Arab kentine göndermiştir (Martin, 2018, s.549).

Dolaylı yoldan yürütülen çatışmalar ABD'nin 23 Eylül 2014'te DEAŞ'a Rakka'da düzenlediği hava saldırısıyla doğrudan müdahale halini almıştır. ABD'nin doğrudan müdahalesini müteakiben İngiltere, Birleşik Arap Emirlikleri, Bahreyn, Suudi Arabistan, Ürdün ve Katar ortaklaşa hava saldırıları düzenlenmiştir (CNN, 2014). Bu süre içerisinde savaşın odak noktası DEAŞ’ın ele geçirdiği bölgeler olmuştur. Örneğin, DEAŞ 2014 yılının Ekim ayında Kobani'yi kuşatınca $\mathrm{ABD}$ liderliğindeki koalisyon güçleri havadan terör örgütünü bombalamıştır. Karadan ise YPG, DEAŞ’a saldırılar düzenleyerek şehri ele geçirmiştir. Suriye rejimi yerine karadan YPG'nin saldırılarda bulunması Esed yönetiminin zımni bir şekilde YPG'nin kendisini temsil etmesine müsaade etmesi anlamına gelmektedir. Ancak YPG'nin yerel halka yönelik saldırıları nedeniyle, Suriye dışına yoğun bir göç dalgası yaşanmıştır.

Rusya'nın iç savaşa doğrudan müdahalesi ise Beşar Esed'in çağrısı ile gerçekleşmiştir. Rusya 30 Eylül 2015'te DEAŞ ve onunla savaşan ÖSO'ya hava 
saldırısı düzenlemiştir. Bu durum Rusya ve Türkiye'nin bölgedeki koalisyon düşünceleri arasındaki zıtlığı bir kez daha göstermiştir. Rusya'nın müdahalesinin zamanlaması da oldukça önemliydi. Bunun iki temel nedenden kaynaklandığ1 söylenebilir: Birincisi; Obama yönetiminin YPG'yi Pentagon programı dâhilinde eğitme kararı alması Suriye stratejisini PYD/YPG üzerinden dizayn edeceğinin bir göstergesidir (NYT, 2014). İkincisi, Obama yönetiminin YPG'ye verdiği silah ve mühimmat desteğinin aşırı artmasıyla Suriye rejimi için artık bir tehdit unsuru taşımaya başlamıştır (CNN, 2014). Ancak YPG'ye kısa vadede verilen büyük miktardaki destek (500 milyon \$) ABD'nin kısa sürede sonuç alma amaciyla da açılanabilir. ABD'nin YPG'ye anti-tank füzeleri ve ağır silah yardımı, Rusya'nın ise Esed karşıtı gruplara yoğun hava saldırıları ABD ve Rusya arasındaki bir vekâletler savaşına dönüşmüştür (Kadıoğlu, 2020). İran'ın da Suriye'ye destek vermesiyle, Rusya, Suriye, İran ve Hizbullah koalisyonu, bölgedeki muhalif güçler ve devlet dışı silahlı aktörlere karşı ciddi bir üstünlük kurmuştur (Reuters, 2015).

İç savaşın şiddetinin ve sivil kayıpların her geçen gün artması nedenleriyle BM Güvenlik Konseyi (BMGK) bir toplantı yapmış ve bu toplantı sonucunda ABD ve Rusya'nın anlaşmasıyla BMGK 2168 Numaralı Kararı almıştır. Buna göre; iki devlet tarafından çatışmadan arındırılmış bölgeler ilan edilmiş, ancak bu bölgedeki ateşkesin BM tarafından ilan edilmiş terör örgütlerini kapsamayacağı deklare edilmiştir. Ortak düşman algısı ile bir yandan Suriye rejimi Palmira şehrini Rusya ve İran'ın desteğiyle DEAŞ'tan alırken, diğer yandan YPG'nin de içinde bulunduğu ve en büyük gücünü oluşturduğu Suriye Demokratik Güçleri (SDG) ABD'nin desteğiyle Münbiç ve el-Bab şehirlerini DEAŞ'tan almıştır (Kadığlu, 2020). Ancak, Suriye rejimi ile YPG her bölgede birbiriyle koordineli bir şekilde hareket etmemişlerdir. Örneğin, YPG ele geçirdiği bölgelerde tek taraflı özerklik iddiasını anons ederken, Suriye rejimi buna kesin bir dille karşı çıkmakta ve ele geçirdiği noktaları Suriye rejimine bırakması gerektiğini deklare etmektedir (Reuters, 2016).

Türkiye ise Fırat Kalkanı harekâtı ile DEAŞ'ın kontrolü altındaki Cerablus şehrine Ağustos 2016'da müdahale etmiştir. Bu dönemde Türkiye'nin hedefi PYD/YPG terör örgütünü sınırlarından uzaklaştırmak ve Fırat Nehri'nin batısını güvenlik altına almak olmuştur. Bu sırada $\mathrm{ABD}$ 'nin desteğine güvenen PYD lideri Salih Müslim Türkiye'nin de tıpkı DAEŞ gibi ortadan kaldırılacağı tehdidinde bulunurken, ABD Başkan Yardımcısı Joe Biden PYD/YPG'nin F1rat'ın doğusuna çekilmesi gerektiğini, aksi halde örgütün $\mathrm{ABD}^{\prime}$ nin desteğini 
kaybedeceğini belirtmiştir (ArabNews, 2016). Ancak, Türkiye destekli ÖSO güçlerinin Cerablus şehrini DEAŞ’tan alıp YPG kontrolündeki Münbiç'e yönelmesi ABD ve Türkiye arasındaki çatışmanın başka bir örneğini oluşturmuştur.

Bu dönemde birçok geçici ateşkes ilan edilmiş, ancak ateşkeslerin ömrü oldukça kısa olmuştur. Eylül 2016'da ABD-Rusya anlaşmasıyla ilan edilen ateşkes, ABD'nin Suriye ordusunu Deyrizor kentinde havadan bombalamasıyla yalnızca beş gün sonra sona ermiştir (Yuhas, 2016). Esed rejimi Halep şehrini tamamen DEAŞ'tan temizlediğini duyurduktan sonra Rusya, Türkiye ve İran'ın garantörlüğünde ateşkes ilan edilmiş ve Astana Barış Görüşmeleri yürütülmüştür. 2016'nın sonunda bir buçuk ay süren ateşkesin ardından çatışmalar Suriye'nin farklı şehirlerinde eş zamanlı olarak başlamış, ancak yine de Cenova'da Şubat 2017'de barış görüşmeleri başlatılmıştır (Kadıŏlu 2020). Ancak, Suriye rejiminin Han Seyhun (Khan Shaykhun) şehrinde sivillere yönelik kimyasal silah saldırısından sonra ABD Hava Kuvvetleri Suriye rejiminin Şayrat Hava Üssü'nü bombalamıştır (BBC, 2017).

İç savaşta DAEŞ terör örgütünün kalesi olarak nitelendirilen Rakka şehrinin ABD'nin liderliğindeki koalisyon güçlerinin hava saldırısı ve SDG'nin karadan ablukası sonucu ele geçirilmesi sonucu DEAŞ terör örgütünün Suriye'deki hâkimiyeti Aralık 2017'de sona erdirilmiştir (Reuters, 2017). Ancak DEAŞ'ın ortadan kaldırılmasıyla iç savaş sona ermemiş, PYD/YPG'nin Kürdistan hayali işgal ettiği topraklarda sürmüştür. Bu tehdidi durdurmak isteyen Türkiye, Zeytin Dalı Harekâtı ile Afrin ve Tel Rıfat'taki PYD/YPG'nin varlığını sona erdirmeyi amaçlamıştır.

2018 yılında Duma şehrini muhalif gruplardan almak isteyen Esed rejimi Nisan ayında 70 kişinin ölümüne ve 500'den fazla kişinin yaralanmasına neden olan bir kimyasal silah saldırısı düzenlemiş ve şehri kontrolü altına almıştır (Ensor, 2018). Batı koalisyonunun çağnısıyla toplanan BMGK ise Rusya'nın muhalefeti nedeniyle herhangi bir karara varamamıştır. Bunun akabinde ABD, İngiltere ve Fransa liderliğindeki Batı konsorsiyumu Suriye hükümetinin hava üslerini bombalamıştır (AlJazeera, 2018).

2019 yılında savaş ÖSO, diğer muhalif gruplar, YPG ve Suriye rejimi arasinda gerçekleşmiştir. Rusya, Türkiye ve İran öncülüğündeki barış görüşmeleri ise yine sonuçsuz kalmıştır. Astana görüşmeleri bu dönemde gerçekleştirilen ama sonuçsuz kalan en önemli barış girişimidir (Kadıŏlu, 2020). Ekim 
2019'da YPG'nin Suriye'nin kuzeyinde tek taraflı özerklik ilan etmesiyle Türkiye hem sınır güvenliğini sağlamak, hem de göç hareketlerini önlemek amacıyla bir barış harekâtı daha düzenlemiştir. Barış Pınarı Harekâtı adı verilen bu operasyon ile Türkiye'nin $32 \mathrm{~km}$ sınırında bir güvenli bölge oluşturarak 3,6 milyon Suriyeli sığınmacının bu bölgeye yerleştirilmesi ve Türkiye sınırlarında bir PKK-PYD terör devleti kurulmasının engellenmesi amaçlanmıştır. Operasyonun başlamasından 13 gün sonra Putin ve Erdoğan, YPG öncülüğündeki SDG'nin Türkiye sınırından $32 \mathrm{~km}$ uzağa çekilmesi için ateşkes ilan edilmesine ve bu bölgede Rus ve Türk askerlerinin ortaklaşa devriye faaliyetleri yürütmesini de içeren Soçi Mutabakatı'nı imzalamışlardır (Evrensel, 2019).

Sınırı korumakla görevli Türk askerlerinin bölgede gözlem noktalarına intikali sırasında 27 Şubat 2020'de Türkiye savaşın başladığ günden bugüne en ağır kaybı yaşamıştır. Rusya destekli Suriye hava kuvvetleri Türk Silahlı Kuvvetleri'nin konvoyunu bombalayarak 34 Türk askerini şehit etmiştir. Bunun sonucunda Türkiye Suriye rejimini silahlı insansız hava araçları, sınırda konuşlandırılmış orta menzilli top bataryaları ve Suriye içindeki ÖSO güçleri yoluyla ağır kayıplara uğratmıştır. Esed rejiminin Suriye'nin kuzeyindeki sivillerin en önemli yaşam alanı olan İdlib'i ele geçirmek istemesi hem kentteki olası katliam tehdidi, hem de Türkiye'ye yönelik potansiyel bir göç dalgası nedeniyle Türkiye açısından ciddi bir tehdit olarak görülmüştür (Hürriyet, 2020). Saldırıdan birkaç gün sonra Erdoğan Putin'i Rusya' da ziyaret etmiş ve iki ülke arasında İdlib'te ateşkes ilan edilmesi kararı 5 Mart 2020'de alınmıştır. Ancak 2020'nin Mart ayı geldiğinde halen Suriye iç savaşı devam etmekte ve savaşın önümüzdeki günlerde sona ereceğine ilişkin herhangi bir emare görülmemektedir.

\section{Teorik Yaklaşım: İç Savaş, Yayılma Etkisi ve Sığınmacılık Sorunu}

İkinci Dünya Savaşı'ndan sonra etnik, ulusal ve mezhepsel çatışmaların artmasıyla iç savaşla ilgili çalışmalar önem kazanmıştır. Savaş çalışmaları alanında dünyanın en bilinen teorisyenlerinden biri olan Stathis Kalyvas iç savaş kavramını kana susamış olmayan ve şiddete bulaşmak istemeyen insanların taleplerini yerine getirmek için bir fursat olarak nitelendirmektedir (Kalyvas, 2006). Fakat iç savaşlar genelde kanlı eylemlere ve çok sayıda can kaybına neden olmaktadır. Kalyvas (2006, s.3) bunun nedenini anlamak için iç savaşın 
tarihsel arka planına bakmak gerektiğini ve toplum içinde var olan grup aidiyetleri ve farklı kimliklerin radikalleşmesinin iç savaşa neden olduğunu belirtmektedir.

İç savaş kavramı etno-ulusalcı çatışma, devrim, isyan ve ayaklanma gibi farklı bağlamları içeren karmaşık bir kavramdır. İç savaşın başlangıç zamanına ve nedenlerine ilişkin çalışmalar (Collier vd., 2003; Gurr, 1980); iç savaşın toplumsal ve sosyal kökenlerinin neler olduğu (Skocpol, 1979); etnik, ulusalc1 ve diğer iç savaşların nasıl barışçıl yollarla sonlandırılabileceği (Walter, 1997; Kadıoğlu, 2020); iç savaşın toplumsal düzeyde nasıl sona erdirileceği, barış inşası ve çatışma sonrası yeniden inşa süreçleri (Bass, 2000; Woodward, 2007) iç savaş literatüründe ele alınan önemli konulardandır. Small ve Singer (1982, s.210) iç savaş kavramını birbirlerine direnen farklı grupların olduğu, resmi hükümetlerin de dâhil olduğu ve daha çok şehir merkezlerinde görülen askeri olayların oluşturduğu bir silahlı çatışma olarak tanımlamaktadır. Suriye iç savaşı gerek şiddet eylemleri ve çatışmanın boyutları, gerekse mevcut rejimin savaşan taraflardan biri olması yönleriyle bu teorik yaklaşıma uymaktadır.

İç savaşın en temel özelliklerinden biri savaşa dâhil olan grup veya kitlelerin bölgesel özerklik iddialarıdır. Bunun yanında, savaşa dâhil olan gruplar koalisyon oluşturabilir ya da birbirlerinden bağımsız hareket edebilir, uluslararası düzeyde tanınabilir ya da izole edilebilir (Kalyvas, 2006, s.18). Bu grupların terörist örgüt ya da yasal zeminini kaybetmiş bir hükümet olması onların uluslararası toplumdan izole edilmelerine yol açabilir. Bu durum, iç savaşın olası sonuçlarından biri olarak kabul edilebilir. İç savaştaki devlet dışı aktörlerin dış destek alması ya da yerel kaynaklardan beslenmesi bu grupların hedeflerine ulaşabilmesi için elzemdir. Bu varsayımların Suriye iç savaşında gerçekleşip gerçekleşmediği bir sonraki bölümde ayrıntılı bir şekilde analiz edilecektir.

İç savaşa ilişkin teorik yaklaşımlar şiddetin kaynağının ve nedenlerinin iç savaşta belirleyici unsur olduğunu öne sürmektedir. Galtung (1985) yapısal şiddet kavramını toplumdaki sosyal ve ekonomik baskıyı açıklamak için kullanmıştır. Galtung'a göre savaşın sona ermesi için savaşa neden olan yapısal nedenler ortadan kaldırılmalıdır. Shearer (1997) ise tam tersi bir yaklaşımla iç savaşların çoğunun askeri başarı ile sona erdiği ve askeri taktiklerin üstesinden gelemeyeceği bir iç savaş durumunun söz konusu olmadığını öne sürmektedir. Bu yaklaşım literatürde ciddi bir biçimde eleştirilmiştir. Burton 
(1990a) kimlik, tanınma ve güvenlik gibi insan ihtiyaçlarının şiddete yol açtığın belirtmektedir. Bu şiddet eylemlerinin sona ermesi için ortak zeminde anlaşılması, yani sıfır toplamlı bir yaklaşımdan ziyade, savaşın bütün taraflarının en az minimum amaçlarına ulaştı̆̆ bir kazan-kazan felsefesinin benimsenmesi elzemdir (Burton, 1990b). Wallensteen (2007) iç savaşların birçok farklı katman ve aktörden oluşan karmaşık bir yapıya sahip olduğu ve bu sürecin etkili bir çatışma çözümü yaklaşımı ile yönetilebileceğini savunmaktadır. Bu yaklaşım, özellikle Suriye iç savaşının Türkiye ve uluslararası organizasyonlar özelinde nasıl yönetilmeye çalışıldığı bağlamında değerlendirilecektir.

İç savaşın yaşandığı devlet mal olduğu can kaybının yanında, siyasi, ekonomik, kültürel ve sosyal alanlarda ciddi anlamda tahribata uğrayabilir. Bu devlet kadar etkili olmasa bile iç savaşa komşu olan devletlerde de benzer alanlarda olumsuz etkiler görülebilir. Bu etkilerin en önemlilerinden biri güvenlik anlamında ortaya çıkan sorunlardır. Savaşta yaşanan şiddetin komşu ülkelere yayılması iç savaşın beklenen sonuçlarından biridir. Literatürde yayılma etkisi (spillover effect) olarak yer alan çatışmanın şiddetinin komşu ülkelere yayılması farklı mekanizmalar dâhilinde kendini göstermektedir. Bunlardan ilki iç savaş yaşanan ülkede devlet dışı silahlı örgütlerin teknik ve askeri kapasitelerinin arttırılmasına neden olduğu yönündeki varsayımdır. Yayılma etkisi, devlet dışı silahlı örgütlerin kolayca ve düşük bedelle elde ettiği silah ve mühimmatın komşu ülkelerde kullanılabilmesi, sınır ötesinde kolaylıkla barınabilmeleri ve teknik bilgi akışı gibi avantajlar sağlamaktadır (Salehyan, 2007). Bu durum terör örgütlerinin komşu ülkelerde saldırılarına devam etmeleri için cesaretlendirici bir rol oynayabilir (Carmignani ve Kiler, 2016, s.111). Bunun yanında iç savaş farklı ülkelerdeki terör örgütlerinin etnik gruplar arasındaki bağlantıları kuvvetlendirici bir rol oynayabilir (Lake ve Rothschild, 1998). Örneğin, Kolombiya'daki çatışma ortamının sınır komşuları olan Venezuela, Peru, Ekvator, Brezilya ve Panama'ya sıçraması yayılma etkisinin komşu ülkelere yansımasına önemli bir örnektir (Millett, 2002). Yayılma etkisi, kimlik çatışmanın yayılması için tetikleyici bir rol oynayabilir (Buhaug ve Gleditsch, 2008; de Groot, 2011). Suriye iç savaşı bu varsayımlara benzer bir şekilde terör örgütlerinin komşu ülkelere şiddet eylemleri yaydığ 1 bir örnek teşkil etmektedir. DEAŞ ve PYD/YPG terör örgütlerinin Suriye'deki saldırıları Türkiye başta olmak üzere birçok komşu ülkede kendini göster- 
miştir. DEAŞ terör örgütünün Türkiye'deki saldırıları yüzlerce insanın hayatına mal olmuştur. PKK'nın Suriye kolu olan PYD/YPG terör örgütü ise Suriye iç savaşında edindiği kazanımları Türkiye'deki PKK ile birleştirme ve Kürt etnik kimliği üzerinden özerk bir Kürt devleti kurma amacı taşımaktadır. Aslında 1984'te PKK ilk terör eylemini gerçekleştirdiğinden beri Suriye PKK'ya destek vererek Türkiye'yi güçsüzleştirme yolunu izlemişti. Literatürde buna kötü komşuluk (bad neighbourhood) denmektedir (Buhaug ve Gleditsch, 2008). Suriye iç savaşı başladıktan sonra ise PKK'nın Suriye kolu olan PYD'nin amacı bu kez Suriye'de toprak elde etmek olmuştur. Yayılma etkisinin terörizm ve çatışma açısından Türkiye'yi nasıl etkilediği sonraki bölümde incelenecektir.

İkinci temel güvenlik problemi ise iç savaştan kaçan sığınmacılar dolayısıyla ortaya çıkan güvenlik zaaflarıdır. Mültecilerin hukuki durumu $1951 \mathrm{Ce}-$ nevre Sözleşmesi ile tanımlanmıştır. Sözleşmeye göre sığınmacı işkence, savaş ya da şiddet nedeniyle ülkesini terk etmek zorunda bırakılan kişidir (UNCSF, 1951). Mevcut literatürde sığınmacılıkla ilgili birçok çalışma sığınmacı hareketlerinin çatışmanın bir sonucu olduğuna yöneliktir (Azam ve Hoeffler, 2002; Moore ve Shellman, 2004; Weiner, 1996). Ancak sığınmaciların çatışmanın bir nedeni olabileceği gözden kaçmaktadır. Sığınmacıların savaştan kaçıp başka ülkelere sığınması silahların, terör örgütü üyelerinin kolaylıkla sığınılan ülkeye taşınmasına ilişkin zaafları da beraberinde getirmektedir. Eğer yeterli düzeyde kontrol ve takip edilmezse, mülteci kampları ve mültecilerin yaşadığı diğer bölgeler terör örgütleri ve gerilla gruplarını ideolojik yayılmaları ve eleman kazanmaları için uygun ortamı oluşturabilir (Carmignani ve Kiler, 2016, s.111). Salehyan ve Gleditsch'e (2006, s.338) göre ise sığınmacılar muhalif grupların ve silahlı örgütlerin şebekelerinin yayılmasını kolaylaştırıc bir etki yapmaktadır.

Sığınmacıların ev sahibi ülke içindeki etnik kompozisyonu değiştirmeleri mültecilik sorunun doğal sonuçlarından biridir. Bu durum uzun dönemde ev sahibi toplum içinde bir çatışma unsuru yaratabilir. Özellikle kültürel, sosyal, dini ve dil ile ilgili doğuştan gelen özelliklerin uyuşmaması ev sahibi toplum ile savaştan kaçan sığınmacıların etnik kimlikleri arasında bir çatışma unsuru doğurabilir. Bu durum, iki toplum arasında ortak diyalektiğin oluşmasını engelleyebilir. Carmignani ve Kiler' in (2016, s.111) öngördüğü gibi, büyük s1ğınmacı dalgaları ev sahibi toplum içinde sosyo-politik gerilim yaratıp o toplumda istikrarsız bir ortama neden olabilir. Büyük sığınmacı dalgaları etnik 
sorunları ağırlaştırabilir ve popülasyonda ortaya çıkaracağı değişim neticesinde ulusal güç dengesini değiştirerek sorunu daha da karmaşık bir hale büründürebilir (Brown, 1996, s.576). Örneğin, Hindistan'ın kuzey doğusuna Bangladeş'ten gelen yoğun mülteci akını neticesinde Hintli yerel nüfus ülke içinde yer değiştirmek zorunda kalmış ve bu durum iki toplum arasında çatışmalara yol açmıştır (Ganguly, 1996; Salehyan ve Gleditsch, 2006). Dolayısıyla, sığınmacılar ev sahibi devlet tarafından ulusal güvenlik sorunu olarak görülebilir (Loescher, 1993, s.8). Sığınmacılar aynı zamanda ekonomik anlamda olağanın dışında bir rekabete yol açıp, ikamet ettikleri bölgedeki demografik yapıyı değiştirebilirler (Salehyan ve Gleditsch, 2006, s.341). Bu tür bir ekonomik ya da güvenlik tehdidi yaratması endişesiyle sığınmacılardan hoşnut olmayan toplumun ya da ev sahibi devletin onları geri göndermeye çalışmaları ise sığınmacıların hayatına mal olabilecek ciddi sıkıntıları beraberinde getirebilir (Weiner, 1992, s.125-126). Dolayısıyla, iç savaşa komşu olan devletlerin sınır güvenliklerini sağlamaları savaşın etkilerini azaltmak için olmazsa olmaz koşuldur. Bu varsayımların Türkiye açısından ne derece geçerli olduğu önümüzdeki bölümde analiz edilecektir.

\section{Suriye İç Savaşı ve Türkiye'nin Güvenliği}

\section{Çatışmanın Yayılması}

Suriye iç savaşında çatışmaya dâhil olan devlet dışı silahlı örgütler, terör örgütleri ve etnik gruplar yalnızca Suriye için değil Türkiye için de ciddi bir tehdit oluşturmaktadır. Suriye'den Türkiye'ye yönelik iki terör örgütü tehdidinden söz edilebilir. Bunlardan ilki; savaşın şiddetinin artmasında temel faktör olan ve Irak ve Suriye'yi içine alan bir şeriat devleti kurma hedefi olan DEAŞ'tır. İkincisi ise; PKK'nın Suriye kolu olan ve onunla aynı ideolojiye sahip olan, Türkiye'nin güneydoğusu, İran'ın kuzey batısı, Irak'ın kuzeyi ve Suriye'nin kuzeyini içeren bir Kürt devleti kurma hayali taşıyan PYD/YPG terör örgütüdür (Kadıŏlu 2019a).

1999 yılında Tevhid ve Cihad Örgütü adıyla Afganistan'da kurulan DEAŞ, örgütlenmesini 2001 yılında Irak'ta tamamlamış ve ABD'nin Irak işgalinde ABD ordusuna saldırılarak düzenleyerek adını duyurmuştur. 2004'te ise Irak el Kaide'si adıyla örgütlenmiş, 2006'da ise Irak'taki diğer radikal örgütlerle birleşip Mücahitler Şura Konseyi'ni kurmuştur. Örgüt Ekim 2006'da 
Bağdat' 1 da içine alacak şekilde Irak'taki altı şehri kapsayan -sözde-Irak İslam Devleti kurduğunu ilan etmiştir. 2011'de ABD'nin Irak'1 terk etmesiyle daha geniş hareket alanı bulmuştur. Suriye'deki iç savaştan kaynaklanan otorite boşluğu sayesinde 2013 yılında Suriye'nin Rakka şehrini ele geçirerek ismini Irak Şam İslam Devleti (IŞID) olarak değiştirmiştir (İçişleri Bakanlığı, 2017, s.6). Bundan sonra da Arapça ismi olan DEAŞ ile anılmıştır. Dolayısıyla, örgüt Suriye iç savaşı ile bir anda peyda olan bir terör örgütü değildir.

T.C. İçişleri Bakanlığı'nın ‘Türkiye'nin DEAŞ ile Mücadelesi” adıyla yayınladığı resmi rapora göre, DEAŞ ve el-Kaide terör örgütleri arasındaki bağlantı 2014 yılında DEAŞ’ın hilafeti geri getirdiğini, Ebubekir al-Bağdadi' yi halife olarak belirlediğini ve Musul'u da ele geçirerek Irak ve Suriye'yi içine alacak bir hilafet devleti kurma iddiası nedenleriyle kopmuştur (İçişleri Bakanlığı, 2017, s.6). Rapor, terör örgütünün faaliyetlerini ve sonuçlarını şöyle açılamaktadir:

DEAŞ terör örgütü yalanlar üzerine kurulu (sözde) hilafeti ve devletiyle, cihad kavramını kirleterek, şehitlik makamının itibarını zedeleyen intihar eylemleri ile insanları hürriyetlerinden mahrum bırakıp, yaptıkları işkence, katliam, terör, soykırım gibi insanlık suçları ile en büyük zararı bölge halklarına ve İslam dünyasına vermektedir (İçişleri Bakanlığı, 2017, s.11).

Irak ve Suriye merkezli bir terör örgütü olmasına rağmen, DEAŞ dünyanın farklı bölgelerinde intihar eylemi, yalnız kurt, silahla kalabalık yerlerde sivillere yönelik saldırı gibi yöntemlerle birçok farklı saldırı gerçekleştirmiştir. Örneğin, 2016 yılında ABD'nin Florida eyaletinde Afganistan kökenli bir Amerikalı olan Omar Mateen bir gece kulübünde otomatik tüfekle 49 kişiyi öldürmüş, 53 kişinin de yaralanmasına neden olmuştur. Saldırı sırasında polisi arayan Mateen DEAŞ’a bağlılık yemini etmiştir (Zapotosky ve Berman, 2016). Dolayısıyla, bu eylemin tek kişilik, herhangi bir grup desteği içermeyen, terör örgütüne ideolojik bağlllık içeren bir yalnız kurt terör eylemi olduğunu söylemek mümkündür.

DEAŞ Türkiye' de de çok sayıda terör eyleminde bulunmuştur. DEAŞ saldırıları nedeniyle 2014-2017 yılları arasında 315 kişi hayatını kaybederken, 1345 kişi de yaralanmıştır. 


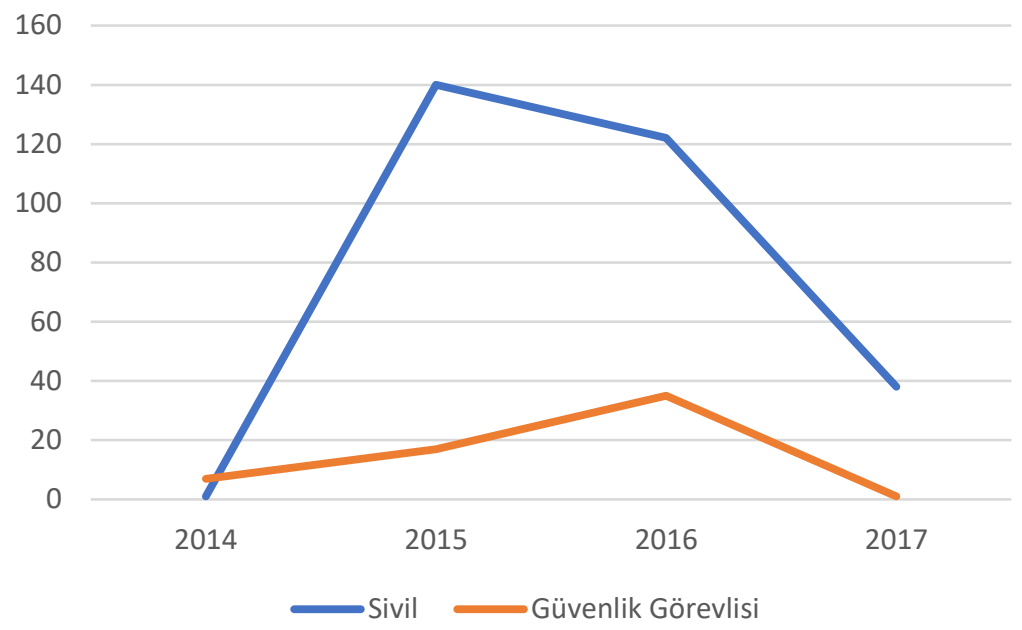

Şekil 1. DEAŞ'ın Düzenlediği Terör Saldırılarında Hayatını Kaybedenler (İ̧işleri Bakanlı̆̆ı, 2017)

Şekil 1'de de görüldüğü gibi DEAŞ’ın Suriye iç savaşında yarattığı tehdit ve can kaybının artmasına paralel bir şekilde terör tehdidi Türkiye'ye yayılmıştır. Salehyan'ın (2007) varsayımına benzer şekilde terör örgütlerinin sahip oldukları silahları kolayca komşu ülkelerde kullanabilmesi, çatışmanın şiddetini Türkiye'ye taşıdığını göstermektedir. Bunun için terör örgütlerinin finansal kaynağı hedeflerine ulaşabilmesi için büyük öneme sahiptir. ABD'nin Ulusal İstihbarat Müdürlüğü'nün ISIL Finances: Future Scenaries (DEAŞ’ın Finans Kaynakları: Gelecek Senaryoları) resmi raporuna göre DEAŞ birçok farklı gelir kaynağına sahiptir. Bunlardan Finans Konseyi silah ve petrol satışlarından elde edilen gelirlerin yönetimini yapmaktadır (DNI, 2016). DEAŞ'ın Irak ve Suriye'de el koyduğu petrol sahaları ve rafinelerinden büyük miktarda gelir sağladığı ve bu gelirleri nakit, Iraklı iş insanları yoluyla, Ortadoğu'daki döviz büroları ve Bitcoin gibi sanal paralar yoluyla elde ettiği belirtilmektedir. Bunun yanında uyuşturucu ticareti, adam kaçırma, insan kaçakçılığı, dış destekler ve bağışlar önemli gelir kaynakları arasındadır (DNI, 2016). Bu sayede yalnızca Suriye'de değil, Türkiye başta olmak üzere komşu ülkelerde saldırılar için gerekli finansal kaynağa sahip olmaktaydı. 


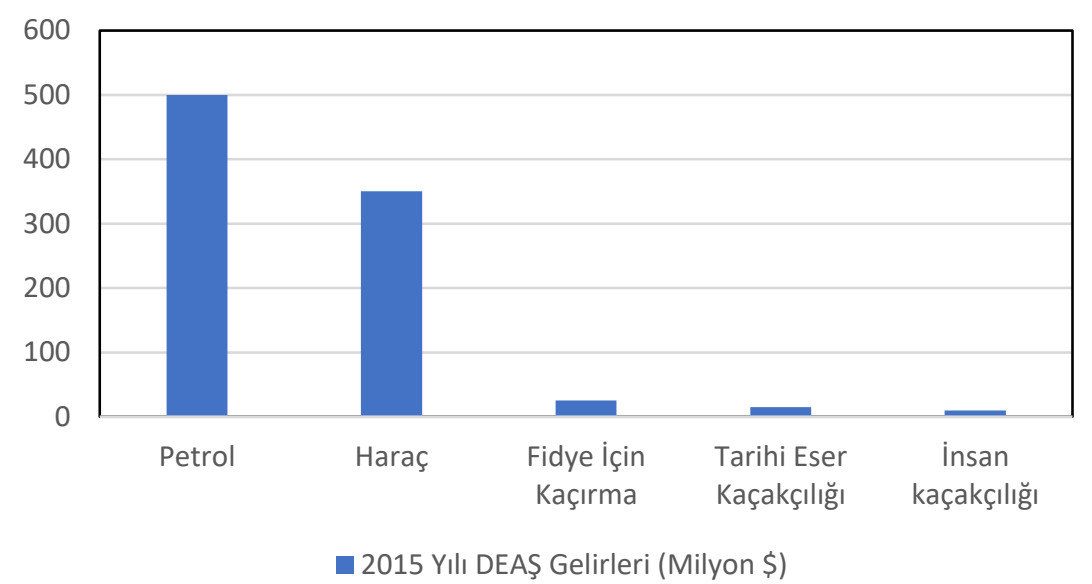

Şekil 2. 2015 Yılı DEAŞ'ın Elde Ettiği Tahmini Gelirler (US Treasury, 2016)

ABD Ulusal İstihbarat Dairesi'nin raporuna göre DEAŞ’ın yalnızca 2015 yılında elde ettiği gelirlerin toplamı 1 Milyar \$'ı aşmaktadır (DNI, 2016). Bu gelirlerden fidye için insan kaçırma (25 milyon \$), tarihi eser kaçakçllı̆ 1 (15 milyon \$) ve insan kaçakçlığı (10 milyon \$) toplam pay içinde küçük bir yer tutuyor gibi görünse de, bu bile toplamda bir terör örgütü için önemli bir miktardır (Şekil 2). Rusya Uyuşturucuyla Mücadele Dairesi Başkanı'nın açılamasına göre ise DEAŞ’ın uyuşturucu ticaretinden elde ettiği yıllık gelir 500 milyon \$'ın üstündedir (RT, 2015). Bunun yanında, Körfez ülkelerinden yapılan bağışların DEAŞ’ın Irak, Suriye ve komşu ülkelerdeki faaliyetleri için dış destek sağladığı düşünülmektedir. Kanıtlanmamış olsa bile Katar ve Suudi Arabistan DEAŞ’a maddi yardımda bulunmakla suçlanmışlardır. Örneğin; Irak Başbakanı Maliki Suudi Arabistan ve Katar'ın DEAŞ'ın şiddet eylemlerini finanse ettiğini iddia etmiştir (Reuters, 2014a). Benzer şekilde, Almanya'nın Kalkınma Bakanı Gerd Müller Katar'ın DEAŞ'ı hem silahlandırdığını, hem de maddi destek verdiğini ileri sürmüştür (Reuters, 2014b). Bu destekten en çok etkilenen ülkelerin başında Türkiye gelmektedir. DEAŞ Türkiye'nin Irak ve Suriye sınırlarını avantaj olarak kullanmış ve sahip olduğu bu büyük maddi kaynak sayesinde gerekli personel ve mühimmata kolaylıkla erişerek terör olaylarının Türkiye'nin farklı bölgelerine yayılmasına neden olmuştur. 


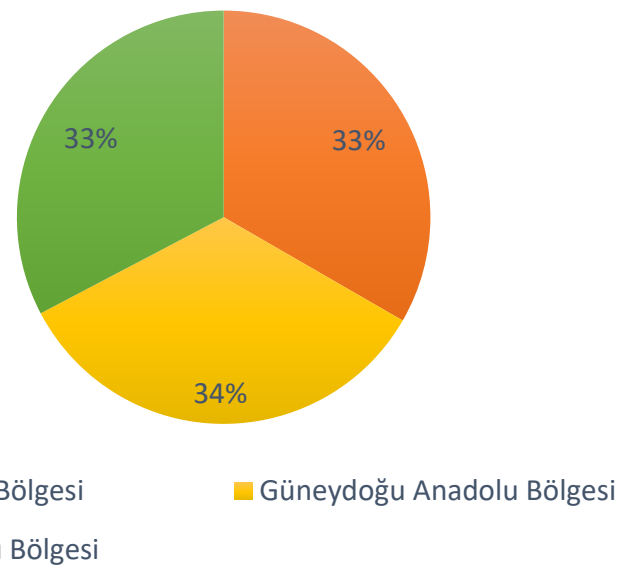

Şekil 3. DEAŞ'ın Bölgelere Göre Türkiye'deki Saldırılan (İçişleri Bakanlı̆̆ı, 2017)

DEAŞ’ın Türkiye'deki saldırılarının coğrafi bölgelere göre yayılmasına bakılacak olursa, üç bölgede birbirlerine yakın oranda can kaybıyla sonuçlanan terör saldırılarında bulunduğu görülmektedir (Şekil 3). Bunun yanında Akdeniz Bölgesi'nde de terör saldırısı düzenlemiş, bombalı saldırılar sonucu dört vatandaş yaralanmıştır. Diğer üç bölgede ise herhangi bir terör saldırısı gerçekleşmemiştir. Marmara ve İç Anadolu Bölgeleri'nde gerçekleştirilen eylemler büyük şehirlerde, İstanbul ve Ankara'da ses getirmesi hedeflenerek gerçekleştirilmiştir. Bunun tek istisnası; Niğde'de yol kontrolü sırasında DEAŞ'lı teröristlerin ateş açması sonucu gerçekleşen saldırıdır. Bunun dişında DEAŞ Türkiye'nin güney sınırlarını kullanarak bölgesel eylemlerini Güneydoğu Anadolu Bölgesi'nde gerçekleştirmiştir. Bu da terörün yayılma etkisinin sadece iç savaşa komşu olmakla değil, bununla birlikte Türkiye'de coğrafi yakınlık ile de ilişkili olduğunu göstermektedir. Coğrafi yakınlık sadece sınır komşuluğu ile açklanabilecek bir unsur değildir. Suriye iç savaşında da görüldüğü gibi, daha spesifik olarak kaynak ülke ile hedef ülke arasindaki birbirine yakın bölgeleri tasvir eden bir terimdir.

Yayılma etkisinin Türkiye'nin güvenliğine ikinci temel yansıması ise PKK'nın Suriye kolu olan PYD/YPG terör örgütüdür. 2003 yılında Kürtler tarafından Suriye'de kurulan PYD, PKK ile aynı kökenden gelen ve aynı ideolojiye sahip olan ve PKK gibi Abdullah Öcalan'ı merkeze alan bir anlayışa 
sahiptir. PYD'nin silahlı örgütü YPG Suriye'de iç savaşın başlamasıyla birlikte PKK-PYD'nin Suriye'de bir Kürdistan kurma amacını gerçeğe dönüştürmek için kurulmuştur. Türkiye Cumhuriyeti YPG'nin kuruluşunun ilanından kısa bir süre sonra YPG'yi terör örgütleri listesine dâhil etmiş ve YPG'nin PKK ile ilişkisine ilişkin belgeleri kamuoyuna sunmuştur (İçişleri Bakanlığı, 2017). PKK/KCK üyesi terörist Zind Ruken Wall Street Journal ile yapmış olduğu görüşmede "Zaman zaman PKK'yım, zaman zaman da PJAK, bazen de YPG. Bunlar gerçekten önemli değil. Bunların hepsi PKK'nun bir üyesi" diyerek PKK ve PYD/YPG'nin aslında aynı örgüt olduğunu kabul etmiştir (İçişleri Bakanlığı, 2017, s.39).

T.C. İçişleri Bakanlığı'nın PKK/KCK Terör Örgütünün Suriye Kolu: PYDYPG adlı raporu Abdullah Öcalan'ın 25 Aralık 2001 ve 13 Ağustos 2003 tarihli görüşme notlarında PKK ile PYD/YPG arasındaki ilişkiyi açıkça ortaya koymaktadır:

Dört ülke için önermiştim. İran'da demokratik İslam esprisi ile olmalı. PKK Irak'ta yaşamalı, Güney PKK biçiminde olabilir. Suriye'de Demokratik Birlik Partisi... Savunmamda Suriye Kürtlerin Demokratik Partisi diyordum. Demokratik Birlik Partisi'ni Suriye halkı için de öneriyorum (İçişleri Bakanlığı, 2017, s.10).

Türkiye'nin güneydoğusunu da içine alacak bir Kürt devleti kurma hayali savaşın başladığı ilk günden bu yana Türkiye'de etkisini göstermeye başladı. Sonuçta, yayılma etkisinin en önemli yansımalarından biri Türkiye' de resmi olarak 2013 yılında başlayan Çözüm Süreci'nin Suriye'de iç savaşın şiddetlenmesi ile 2015 yılında sona ermesidir (Kadığlu, 2019b). Bunda PYD/YPG'nin Suriye'de ele geçirdiği kantonların etkisi olduğu yadsınamaz.

PYD/YPG tehdidinin yayılmasının bir başka nedeni; bölgesel ve küresel güçlerin DEAŞ’a karşı koalisyonda PYD/YPG'yi yerel ortak olarak görmeleridir. Bunda Suriye rejiminin meşruiyetini kaybetmesi ve ABD'nin liderliğindeki Batı koalisyonu tarafından desteklenmemesinin etkisi büyüktür. Bu bağlamda, DEAŞ ve PYD/YPG'nin yayılma etkisinin birbirlerine bağımlı olduğu söylenebilir. Bu durum Batı koalisyonunun Suriye'de DEAŞ’a karşı mücadelede PYD/YPG'yi partner olarak kullanmasına yol açmıştır. Türkiye ise yayılma etkisinin önüne geçmek için, Suriye sinırlarında 2016-2017 yıllarında Furat Kalkanı, 2018 yılında Zeytin Dalı, 2019 yılında ise Barış Pınarı Harekâtları'nı gerçekleştirdi. Bu harekâtların temel amaci; Türkiye'nin sınır güvenliğini sağlamak ve sınırlarında bir PYD/YPG terör devleti ya da otonom bölgesi 
oluşturulmasını önlemekti. Ancak bu yayılma etkisinin önlenmesi çabası başta $A B D$ ve Rusya olmak üzere birçok küresel gücün tepkisiyle sonuçlandı. Dolayısıyla, PYD/YPG'nin yayılma etkisini anlayabilmek için, bu etkinin uluslararası düzlemdeki izdüşümünün incelenmesi gerekmektedir. Türkiye'nin başlangıçta Batı koalisyonunda yer almaması ABD'nin YPG'ye verdiği desteğin, Türkiye'nin toprak bütünlügünü ve sınır güvenliğini tehdit olarak algılaması ile açıklanabilir. Bunun en açık örneği, ABD'nin 2015 y1lında YPG'ye anti-tank füzelerinin de içinde olduğu ağır silahlardan oluşan büyük sevkiyatıdır (NYT, 2015). Bu silahların savaş esnasında ya da sonrasında Türkiye'ye karşı kullanılabileceği endişesi Türkiye'nin güvenlik kararlarında belirleyici unsur olmuştur. İngiliz Parlamentosu'nun Dış İlişkiler Komitesi yayınladığı raporda PKK ve PYD/YPG arasındaki bağlantıya dair delillere sahip olduğunu ve PYD/YPG'nin PKK'nın uzantısı olduğunu düşünmekle birlikte, PYD/YPG'ye Suriye' deki iç savaş sırasında hava saldırısı desteği verdiğini kabul etmektedir (FAC, 2018). Parlar-Dal'ın (2016: 1407) belirttiği gibi Türkiye'nin başlangıçta DEAŞ karşıtı koalisyonda yer almaması ABD'nin tepkisine neden oldu. Ancak Türkiye daha sonra ABD'nin eğit-donat programı çerçevesinde Iraklı Kürt peşmergelerin eğitimine ve Türkiye sınırlarını kullanarak DEAŞ’a karşı savaşması için gönderilmesi çalışmasına dâhil olarak DEAŞ karşıtı koalisyonda yer almıştır (Martin, 2018, s.549).

Esed rejimi ve PYD/YPG'nin Suriye'de birlikte hareket ettiğine yönelik bulgular Türkiye'nin PYD/YPG'ye yönelik daha da temkinli bir tutum takınmasına neden olmaktadır. PYD/YPG Suriye'nin kuzeyinde büyük bir bölgeyi kontrolü altında tuttuğu ve otonom bölge ilan ettiği için Suriye rejimi ve YPG arasında zayıf bir bağlantı olduğu iddia edilmiştir (Khan ve Khan, 2017, s.594). Ancak, DEAŞ'ın Suriye' den temizlenmesine yönelik yürütüldüğü duyurulan ortak operasyonların DEAŞ ortadan kaldırıldıktan sonra diğer muhalif gruplara karşı sürdürülmesi, bu iddianın sorgulanmasını gerekli kılmaktadır (Kadığlu, 2020). Örneğin; İdlib'i muhaliflerin elinden almak için Şubat 2020'de Esed rejimi askerleri ve YPG birlikte çok sayıda saldırı düzenlemiştir (Milliyet, 2020). Aynı zamanda Esed rejimi askerleri PYD/YPG'nin otonom bölge iddiasındaki alanlarda iki taraf arasında herhangi bir çatışma yaşanmamıştır. Bunun aksine, Esed rejimi ve PYD/YPG arasında ticaret ilişkileri olduğu ispatlanmıştır (Acun ve Keskin, 2017, s.58).

İçişleri Bakanlığı'nın raporuna göre 2017 yılı içinde PYD/YPG tarafından 14 saldırı düzenlenmiş ve bu saldırılar neticesinde bir vatandaş şehit olmuş, 
yedi vatandaş yaralanmıştır. PYD/YPG aynı zamanda dört vatandaşı da kaçırmıştır (İçişleri Bakanlığı, 2017). Bu saldırılara karşılık 17 PKK-PYD üyesi Suriye sınırları içinde etkisiz hale getirilmiştir. Bu durum PKK-PYD üyelerinin Suriye sınırın kullanarak Türkiye'ye saldırılarda bulunduğunu göstermektedir. Ayrıca, Suriye'nin kuzeyindeki otorite boşluğunun terörün yayılma etkisini kolaylaştırdığı görülmektedir.

\section{Sığınmacılar Sorunu}

Suriye iç savaşı başladıktan hemen sonra şiddetin sivillere sıçramasıyla Suriyeliler ülke dışına göç etmek zorunda kaldı. Bu zorunlu göçün ilk durağı ise Suriye'ye komşu ülkeler olmuştur. Aslında Suriyeli sığınmacıların hedef noktası Avrupa ülkeleri olsa da, bu ülkelerin Suriyeli sığınmacı sorununu kendilerinden uzak tutma çabası, Türkiye'yi ve Suriye' nin diğer komşu ülkelerini tampon bölge olarak kullanma amac nedenleriyle sorunu bölge ülkeleri gögüslemek zorunda kalmıştır (Kadığlu, 2018). Türkiye Suriye iç savaşı başladığından bu yana en fazla Suriyeli sığınmacıya ev sahipliği yapan ülkedir.

Tablo 1. Türkiye'de Geçici Koruma Altındaki Suriyeliler (GÍGM, 2020)

\begin{tabular}{ll}
\hline Y11 & Suriyeli Sayis1 \\
\hline $\mathbf{2 0 1 2}$ & 14,237 \\
\hline $\mathbf{2 0 1 3}$ & 224,655 \\
\hline $\mathbf{2 0 1 4}$ & $1,519,286$ \\
\hline $\mathbf{2 0 1 5}$ & $2,503,549$ \\
\hline $\mathbf{2 0 1 6}$ & $2,834,441$ \\
\hline $\mathbf{2 0 1 8}$ & $3,426,786$ \\
\hline $\mathbf{2 0 1 9}$ & $3,623,192$ \\
\hline $\mathbf{2 0 2 0}$ & $3,576,370$ \\
\hline
\end{tabular}

Tablo 1'de de görüldüğüü üzere, Türkiye'deki Suriyeli sığınmacıların sayısı yıllar itibariyle artan bir trend izlemiştir. Bu durum ekonomik, sosyal, kültürel ve güvenlikle ilgili pek çok sorunu da beraberinde getirmiştir. Suriyeli s1ğınmacıların güvenlik problemine yol açıp açmadıkları teorik düzlemden elde edilen varsayımlardan faydalanarak dört faktör bağlamında incelenebilir: mülteci kampları yoluyla, etnik dağılımdaki değişiklik, suça karışma oranları ve teröre yardım yoluyla.

\footnotetext{
319 Mart 2020 itibariyle Türkiye'de geçici koruma altındaki Suriyelilerin toplam sayısıdır.
} 
Suriyeli sığınmacıların mülteci kampları yoluyla şiddet eylemine yol açıp açmadıklarını anlayabilmek için Türkiye'deki Suriyelilerin ne kadarının kamplarda yaşadığını incelemek gereklidir. 2020 yılı itibariyle Türkiye'de yalnızca beş ilde geçici koruma merkezi, yani barınma merkezleri mevcuttur. Adana, Kilis, Kahramanmaraş ve Osmaniye'deki birer, Hatay'daki üç, toplamda yedi barınma merkezinde 18 Mart 2020 tarihi itibariyle toplam 63,948 Suriyeli sığınmacı yaşamını sürdürmektedir (GİGM, 2020). Bunun resmi rakamlara göre geçici koruma statüsündeki toplam Suriyelilere oranı ise yüzde $1,94^{\prime}$ tür. Suriyelilerin nüfusu iç savaşın devam etmesiyle hızla artmış ve barınma merkezleri yetersiz hale gelmiştir. Dolayısıyla, Suriyeliler savaşın ilk yıllarının aksine artık kamplarda değil, ülke içinde dağınık bir şekilde yerleştiklerinden durum kontrol edilebilir olmaktan çıkmıştır. Carmignani ve Kiler'in (2016, s.111) iddiası, mülteci kamplarının terör örgütlerinin yayılmaları ve personel kazanmaları için uygun ortamı oluşturduklarıydı. Ancak Türkiye'de kamplarda çok az Suriyelinin yaşadığı, bunların sürekli kontrol altında tutulduğu düşünüldüğünde kamplarda teröristlerin ideolojik olarak yayılmalarına uygun bir ortam oluştuğu kanaatine varmak zorlayıcı bir yaklaşım olacaktır.

Büyük sığınmacı dalgalarının etnik sorunları ağırlaştırdığına ilişkin yaklaşım ise Suriyeli sığınmacıların toplam nüfus içinde oluşturdukları yer ve spesifik bir coğrafyada toplanmayı tercih edip etmemelerine göre değerlendirilecektir. Bu sayede gelecekte bölge bazlı güç dengesini ve etnik dağılımı değiştirecek bir sorun ortaya çıkma potansiyeli değerlendirilecektir.

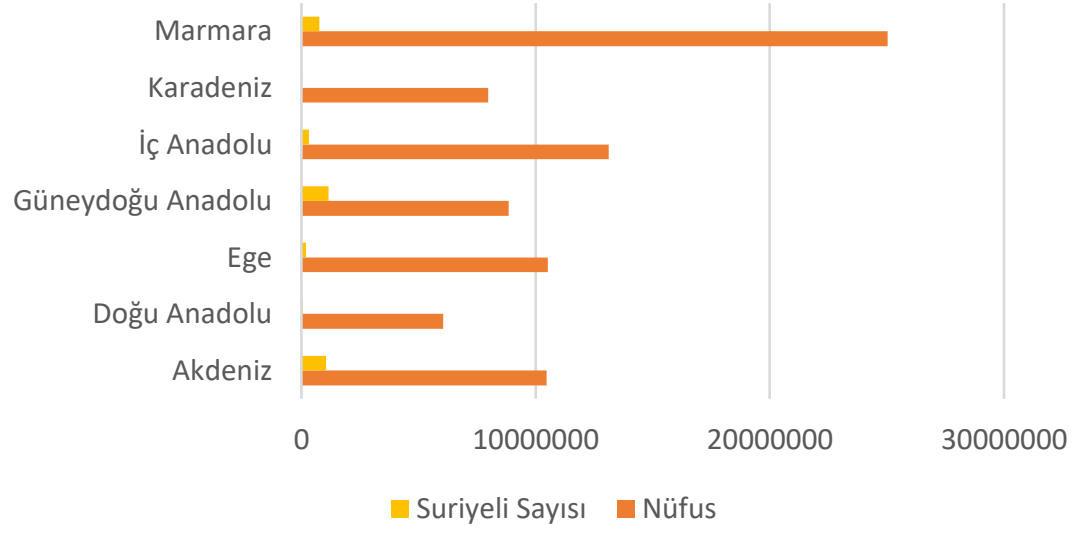

Şekil 4. Coğrafi Bölgelere Göre Nüfuslar ve Suriyeli Sayılan (GİGM, 2020) 
Göç İdaresi Genel Müdürlüğ̈̈'nün şehir bazlı yayınladığı rapor coğrafi bölgelere göre derlendiğinde, bölgeler arasında Suriyelilerin dengeli olmayan bir şekilde dağıldığı görülmektedir. Şekil 4'teki nüfuslara bakıldığında, Suriyelilerin dağılımının bazı bölgelerdeki etnik yapıyı değişikliğe uğratırken, diğerlerinde bölgenin toplam nüfusuna göre sayıca az Suriyeliye ev sahipliği yaptığı için etnik yapıda şu an için ciddi bir değişim yaratmadığı görülmektedir. Kısa dönemde etnik yapıdaki değişikliğin herhangi bir çatışma unsuru doğurmadığı söylenebilir. Ancak etnik yapıda ve etnisite bazlı diğer bileşenlerde ortaya çıkabilecek sorunlar genelde uzun dönemde görülen sorunlardır. Dolayısıyla bu konuda net bir kanaate varabilmek için uzun süre geçmesi gerekmektedir.

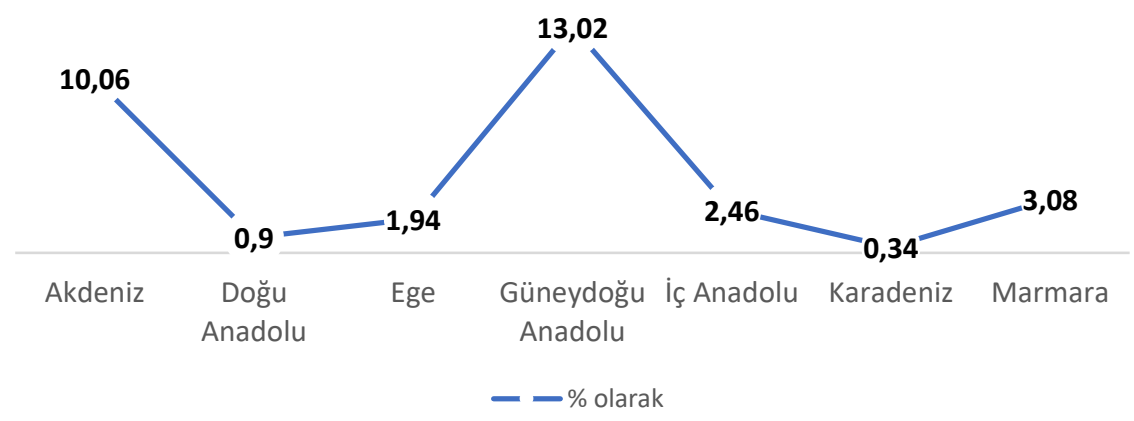

Şekil 5. Suriyeli Sayılarmın Coğrafi Bölge Nïfuslarna Oranı

Şekil 5'te görüldüğü üzere, Suriye'ye coğrafi olarak yakın bölgelerimiz göçün merkezi haline gelmiştir. Hem sayıca hem de oran olarak en çok göç alan iki bölge Güneydoğu Anadolu ve Akdeniz Bölgeleri'dir. Sığınmacıların etnik yapı anlamında bu iki bölgede değişiklik yarattığı söylenebilir. Ancak, Suriyeli sığınmacıların bir ulusal güç olarak varlık gösterip siyasi hak talebinde bulunması gibi bir durum söz konusu değildir. Yine de nüfus oranlarına bakıldığında potansiyel tehlike taşıyabilecek bölgeler olarak Güneydoğu Anadolu ve Akdeniz Bölgeleri gösterilebilir. Bu bölgelerde ise Kilis \%78, Hatay $\% 27$, Gaziantep \%22 ve Şanlıurfa \%22 ile nüfuslarına göre en çok Suriyeli barındıran şehirlerdir (GİGM, 2020). Suriyeli sığınmacıların özellikle bu şehirlerde topluma sosyal uyumu konusunda kapsamlı adımların atılması gerekmektedir. Sığınmacılar Türkiye'ye yerleşerek sosyal, kültürel ve ekonomik 
anlamda Türkiye'ye uyum sağlamaya çalışmaktadırlar. Ancak, Suriyeli s1ğınmacıların önemli bir kısmının kenar mahallelerde komün hayatı yaşadıkları için sosyal uyumlarının gerçekleştirilmesi ve Türkiye toplumuna entegre edilmeleri kolay görünmemektedir.

Bundan sonra en çok göç alan bölge Marmara Bölgesi'dir. Bunda 500,000'e yakın Suriyeli'nin ekonomik gerekçelerle İstanbul'a taşınmasının etkisi büyüktür. Temmuz 2019 'da Suriyelilerin mobilitesini sinırlandırmak ve bir istismar alanı oluşmasının engellenmesi amacıyla İstanbul'daki ekonomik yapıda değişiklik yapacağı endişesiyle İçişleri Bakanlığı aldığı kararla İstanbul'a zorunlu haller dışında geçici koruma statüsüyle Suriyeli kaydı yapılmayacağını açıklamıştır. İçişleri Bakanı Süleyman Soylu alınan kararı şu şekilde açıklamıştır: "İstisnaların dışında İstanbul'da Suriyeli kaydı almıyoruz. Suriyeli kaydına İstanbul kapalıdır.”... "Hiç kimsenin kendi anlayışını başkasına dayatmasına, yerleşik düzeni bozmasına müsaade etmemiz mümkün değildir' (NTV, 2019). Bu açıklamadan da anlaşıldığı gibi, bazı şehirler Suriyelilerin serbest dolaşımından muaf tutulmuştur. Ancak burada etnisite merkezli bir kontrol mekanizmasından çok, ekonomi merkezli bir anlayış ve yerel yönetimlerin yürütülmesinden doğabilecek sıkıntıların önüne geçilmesi anlayışı olduğu söylenebilir. Salehyan ve Gleditsch' in (2006, s.341) sığınmaciların ekonomik anlamda olağanın dışında bir rekabet ortamı yarattı̆̆ına ilişkin öngörülerinin İstanbul özelinde geçerli olduğu söylenebilir.

Türkiye'de Suriyelilerin karıştığı suç oranları güvenlik açısından Suriyelilere özgü bir sorun olup olmadığını ortaya koymak için oldukça önemlidir. İçişleri Bakanlığı'nın basın açıklaması bu oranı göstermek açısından yol gösterici olacaktır:

Tablo 2. Suriyeli Sığınmacılar ve T.C. Vatandaşları Tarafından İşlenen Suç Sayılarn (İçişleri Bakanlığı Basın Açıklamasından Derleyen Kızmaz, 2018)

\begin{tabular}{lll}
\hline Y1l & Türkiye & Suriyeli Siğınmacılar \\
\hline $\mathbf{2 0 1 4}$ & 1.870 .374 & 10.352 \\
$\mathbf{2 0 1 5}$ & 1.858 .120 & 13.557 \\
$\mathbf{2 0 1 6}$ & 1.876 .816 & 14.457 \\
$\mathbf{2 0 1 7}$ (illk 6 ay) & 956.306 & 7.157 \\
\hline
\end{tabular}

Tablo 2' de 2014-2017 yılları arasında toplam adli vakalar ile Suriyeli sığınmacıların karıştığı vakalar karşılaştırmalı olarak gösterilmiştir. Daha sonra 
Anadolu Ajansı'nın (AA) ulaştı̆̆ bilgiye göre 2017 yılının tamamında Suriyelilerin karıştığı olayların toplam asayiş suçlarına oranı yüzde 1,98; 2018 yılının ilk dokuz ayında ise yüzde 1,46 olarak gerçekleşmiştir (AA, 2018). İstatistiki olarak ay ve yıl bazında düzenli bir bilgi olmasa da, işlenen toplam suç oranı içinde Suriyelilerin karıştığı suçların oldukça düşük olduğu söylenebilir. İçişleri Bakanı Soylu ise 7 Temmuz 2019'da yaptığı konuşmada: "Ortalama bir Suriyelinin suça karışma oranı, Türk vatandaşlarımızın yarısından daha az olmasına rağmen bu insanları suç makinesi gibi göstermeye çalışan, bununla ilgili provokatif yayınlar ortaya koyan merkezler var" demiştir (Cumhuriyet, 2019). Aynı zamanda Suriyeli sığınmacıların terör eylemlerine katıldıklarına yönelik herhangi bir bulguya rastlanmamıştır.

Şu ana kadar Suriyeli sığınmacıların yarattı̆̆ ciddi bir güvenlik tehdidi tespit edilmemiş olsa bile gelecekte ortaya çıkabilecek potansiyel sıkıntılar göz ardı edilmemelidir. ORSAM (2015) raporunda güvenlikle ilgili potansiyel sıkıntıları yerel halk ile Suriyeliler arasında çatışma riskinin olması, toplumun artan güvenlik kaygısı, Türkiye'deki siyasi ortam ve tercihler gibi unsurlar olarak saymıştır. Suriyelilere ilişkinin tepkinin yerel halkta provokasyona yol açabileceğine yönelik endişe Gaziantep ve Kahramanmaraş'ta 2014 yılında şiddet eylemlerine yol açmıştır (ORSAM, 2015, s.19). Yine Suriyeli sığınmacılar arasında Esed'e bağlı kişiler, DEAŞ ya da PKK üyeleri ya da sempatizanları olanlar olacağına ilişkin korkunun yer halkın paylaştığı başka bir endişe olduğu söylenebilir. Kızmaz bu konuda yaptığı çalışmada, Suriyelilerin yarattığı güvenlik kaygılarıyla ilgili farklı korku unsurlarından bahsetmiştir: Suriyeli gençlerin gelecekte radikalleşmesine yönelik kaygı, gelecekte terör eylemlerine karışacaklarına yönelik korku, sığınmacılarla yerel halk arasındaki kültür farkında doğacak çatışma, işsizliği arttıracakları ve ekonomiyi olumsuz etkileyecekleri ve yerel halk arasında yabancı düşmanlığının ortaya çıması (Kızmaz, 2018, s.398-399). Taştan ve arkadaşlarının yaptığı anket çalışmasında yerel halka Suriyelilerin güvenlik sorunu oluşturup oluşturmadığına yönelik sorular sormuştur. Bu sorulardan "Suriyeliler geldikten sonra hirsızlık vakalarında artıs oldu mu?' sorusuna evet diyenlerin oranı $\% 62$, "Suriyeliler geldikten sonra şiddet darp, öldürme ve yaralama olaylarında artış oldu" diyenlerin oranı ise \%60 dolayında olmuştur (Taştan, Haklı ve Osmanoğlu, 2017, s.22). Bu durum yukarıda bahsedilen gerçek suç oranlarıyla yerel halkın gözündeki Suriyeli profilinin birbirine taban tabana zıt olduğunu göstermektedir. 


\section{Sonuç}

Bu makalede Suriye iç savaşının Türkiye açısından ne tür güvenlik problemlerine yol açtığı tartışılmıştır. Bu makale iç savaşın Türkiye'nin güvenliğine iki temel alanda etki yaptığını ortaya koymuştur: çatışmanın yayılması ve sığınmacılar sorunu. Türkiye hem coğrafi konumu, hem de kötü komşuluk nedenleriyle on yıllardır PKK terörüyle mücadele etmektedir. Suriye iç savaşıyla birlikte PKK'nın Suriye kolu olan PYD'nin YPG'yi kurmasiyla, terör örgütü Suriye iç savaşına katılmıştır. Böylece Suriye'nin kuzeyi ve Türkiye'nin güneydoğusunu içine alacak bir Kürt devleti kurma hayali gerçeğe dönüştürülmeye çalışılmıştır. Türkiye bu etkiyi bertaraf etmek için Suriye içinde çok sayıda operasyon düzenleyerek sınır güvenliğini sağlamaya çalışmıştır. Ancak Türkiye, $A B D$ ve Batı koalisyonunun PYD/YPG terör örgütüne verdiği destek nedeniyle Suriye'nin kuzey sinırlarının büyük kısmını PYD/YPG'nin kontrol etmesine engel olamamıştır. PKK'nın 1980'li yıllardan bugüne Suriye sınırını kullanarak Türkiye'de pek çok terör saldırısı gerçekleştirdiği düşünüldüğünde çatışmanın yayılma etkisinin ne kadar tehlikeli olduğu anlaşılacaktır.

PYD/YPG'nin yayılma etkisinin yüksek olmasının temel nedenleri; bölgesel ve küresel güçlerin DEAŞ’a karşı koalisyonda bu örgütü yerel ortak olarak görmeleri ve PYD/YPG'ye yaptıkları yoğun silah ve mühimmat, lojistik ve hava saldırısı destekleridir. Bu makale Türkiye'nin yürüttüğü barış operasyonlarının Suriye'nin genelinde kalıc getirememesinin nedeni olarak PYD/YPG terör örgütünün legalleştirilmesi olduğu sonucuna varmıştır. DEAŞ terör örgütü ortadan kaldırıldıktan sonra bile PYD/YPG'nin ele geçirdiği toprakları terk etmemesi ve Suriye'nin kuzeyinde otonom bir Kürt bölgesi oluşturduğunu ilan etmesi bunun açık bir örneğidir. Aynı zamanda makale, Türkiye'ye ABD'nin başını çektiği koalisyon güçleri tarafından PYD/YPG'ye destek verilmemesi nedeniyle baskı uygulanmasının da hem terörle mücadele, hem de çatışmanın yayılma etkisi dikkate alınarak değerlendirilmesi gerektiği sonucuna varmıştır. İngiliz Parlamentosu'ndan elde edilen birincil kaynaklarda da PYD/YPG'nin PKK ile doğrudan bağlantısı olduğuna dair delillere ulaşıldığı teyit edilmiştir.

Suriye iç savaşıyla birlikte, Türkiye'ye yönelik tehdit algısı yalnızca etnik temelli olmaktan çıkmış, dini bir araç olarak kullanan terör örgütü olan DEAŞ 
ile global bir hal almıştır. Türkiye DEAŞ’a karşı mücadelede etkin bir rol oynarken aynı zamanda savaşın yayılma etkisine de maruz kalmış, topraklarında çok sayıda terör eylemi gerçekleşmiştir. Birincil kaynaklardan elde edilen verilere göre, yalnızca üç yıl içinde DEAŞ terör örgütünün Türkiye'de 300'den fazla insanın hayatına mal olduğu görülmüştür. Bu da terör örgütlerinin sahip oldukları silahları komşu ülkelerde kullanabilmesinin, yani çatışmanın yayılma etkisinin bir sonucudur. Bu makale DEAŞ’ın saldırılarının yayılma etkisinin coğrafi olarak Suriye'ye yakın bölgelerle sınırlı kaldığı ve yayılma etkisinin coğrafi yakınlık ile ilişkili olduğunu ortaya çıkarmıştır. Bunun dışında İstanbul ve Ankara'da yapılan terör saldırılarının ise terörün temel hedefi olan toplumda korku yaratma amacına yönelik olarak yapıldığı ortaya konmuştur. Dolayısıyla yayılma etkisinin Türkiye'nin güvenliğine yönelik temel olumsuz etkilerden biri olduğu söylenebilir. Bu çalışmada Türkiye'nin DEAŞ ile mücadelede isteksiz olduğuna yönelik eleştiriler istatistiki bilgiler ve resmi makamların yaptıkları açıklamalar ile değerlendirilmiştir. Bu bağlamda, Türkiye'nin PYD/YPG'yi etkisiz hale getirmek için DEAŞ'ın Suriye'deki faaliyetlerine kayıtsız kaldığı yönündeki eleştirinin dayanaktan yoksun olduğu söylenebilir. Türkiye'nin ABD ile birlikte Iraklı peşmergelerin eğitimini üstlenmesi ve sınırların kullanmasına izin vermesi, ÖSO'ya silah, mühimmat, eğitim ve lojistik destekleri vererek DEAŞ’a karşı savaşta yanında olması ve ülkesinde yaşanan DEAŞ saldırılarına karşı koalisyon güçlerinin yanında yer alması nedenleriyle bu iddianın geçerli olmadığı sonucuna varılmıştır.

Sığınmacılık sorunu Türkiye'nin güvenliğine yönelik en çok tartışılan konuların başında gelmektedir. Bu makale sığınmacıların Türkiye'nin bir güvenlik problemine neden olup olmadıklarını mülteci kampları, etnik dağılımdaki değişiklik, suça karışma oranları ve teröre yardım unsurlarıyla incelemiştir. Göç İdaresi Genel Müdürlüğü'nün yayınladığı istatistiğe göre geçici koruma merkezlerinde yaşayan Suriyelilerin toplam Suriyeli sığınmacılara oranının çok düşük olduğu belirtilmiştir. Aynı zamanda bu kampların kontrolü ve denetimi İçişleri Bakanlığı'nın denetimi altında olduğu için bu kamplarda terör örgütlerinin ideolojik olarak yayılmaları kolay görünmemektedir. Bu teorik varsayımı doğrulayıcı Türkiye'yle ilgili herhangi bir bulguya rastlanmamıştır. Büyük sığınmacı dalgalarının etnik sorunları ağırlaştırdığına yönelik varsayım ise Türkiye'de coğrafi bölgeler bakımından bir veri analizi 
yapılarak değerlendirilmiştir. Bu analize göre; en çok sığınmacıya ev sahipliği yapan bölgeler Güneydoğu Anadolu (\%13,2) ve Akdeniz $(\% 10,06)$ Bölgeleri'dir. Bunun dışındaki diğer bölgelerde etnik dağılımı değiştirecek bir sığınmacı akınına rastlanmamıştır. Bu iki bölge özelinde ise şu anda büyük bir güvenlik sorunu ortaya çıkmamıştır. Bunun yanında, Suriyeli sığınmacıların ulusal bir güç olarak ortaya çıkacağına yönelik herhangi bir emareye de rastlanmamıştır. Ancak Kilis, Hatay, Gaziantep ve Şanlıurfa'da sosyo-kültürel yapıda ciddi bir değişim yaşanabileceği öngörülebilir. Dolayısıyla sığınmac1ların sosyal uyumlarına, kültürel adaptasyonlarına ve iki toplum arasında sürtüşme ortamının önlenmesi bağlamında kapsamlı önlemlerin alınması gerekmektedir.

Suriyeli sığınmacıların şiddet eylemlerini arttırdığı ve problemin kaynağı olduğuna yönelik yerel halkta oluşan önyargı ise İçişleri Bakanlığı' nın verileri yoluyla analiz edilmiştir. Buna göre Suriyeli sığınmacıların karıştığı suç oranı T.C. vatandaşlarının ortalamasının yarısından azdır. Dolayısıyla, Suriyeli sığınmacıların güvenlik tehdidi yarattıklarına yönelik kaygıların aksine, bu araştırma bu anlamda yüksek bir güvenlik tehdidi olmadığını ortaya koymuştur. Ancak, yerel halk içinde sığınmacıların terör sempatizanı ya da destekçisi oldukları yönünde bir korku olabilir. Bu korkuyu aşmak ve iki toplum arasındaki bariyerleri kaldırmak ancak uzun vadede mümkün olabilecektir. Savaş sona erdikten ve geçici koruma statüsü altındaki Suriyelilerin durumu belirlendikten sonra, bu konularda kalıcı adımlar atılmalıdır. 


\section{EXTENDED ABSTRACT}

\section{The Syrian Civil War and Turkey: Conflict, Security and Refugees \\ * \\ İ. Aytaç Kadıŏ̆lu \\ Adryaman University}

The peaceful protests in Syria began in March 2011 criticising high unemployment rates; authoritarianism and corruption, and claiming democratic and fundamental rights, and democratic governance. The protests turned into a civil war when the Assad regime attacked peaceful protesters who claimed President Assad to step down. Since then, the level of violence rapidly increased and hundreds of thousands of people lost their lives. DAESH (Islamic State in Iraq and Syria) and PYD/YPG (Democratic Union Party/People's Defence Units) terrorist groups' attacks, the US and Russia's ambitions on the Middle East and the competition between regional powers deteriorated the civil war. The Syrian civil war deeply affected Turkey in regard to violence, terrorism, migration and socio-cultural issues. In contrast, Turkey did not directly intervene in the conflict for a long time. Instead, Turkey began to support the Free Syrian Army (FSA) against the DAESH, PYD/YPG and the Syrian army. Turkey aimed to secure its borders and to prevent establishing a Kurdish state in northern Syria. The US and other western countries' support for the PYD/YPG led the terrorist group to capture major cities near the Syria-Turkey border. This was followed by the PYD/YPG's declaration of autonomy in northern Syria. This triggered Turkey's direct intervention in Syria. Turkey organised the Operation Euphrates Shield between August 2016 and March 2017, Operation Olive Branch between January and March 2018, Operation Peace Spring in October 2019, which aimed to annihilate terrorist threat in the Syria-Turkey border. In addition, the US and Russia's ambitions to take the Middle East under control prevented to bring the civil war to an end.

How Turkey has been affected by the Syrian civil war has not been sufficiently assessed in the existing literature. This article aims to fill this gap 
by focusing on two major security concerns: the spillover effect and refugees. The first major aspect is the spillover effect which addresses the consequences of the conflict between sub-state armed groups, the Assad forces and regional and international coalition powers. Following the financial, economic and military support for terrorist groups, DAESH and PYD/YPG began to be a security threat for Turkey. Both terrorist groups attacked Turkey many times since their inception. Therefore, the spillover effect is a significant issue to understand affected Turkey since 2011. The second major aspect is the issue of migration which mostly affected the neighbouring countries. As Turkey hosts more than 3,6 million Syrian refugees, whether these refugees caused security issues is another significant issue to be investigated. The article also assesses the right to live of Syrian refugees who have had to leave their home in order to survive. While migration and refugees are seen potential security threats in general, they have not involved in violence in Turkey.

The article utilises primary sources, namely official reports published by the Turkish and British governments and the US administration to understand the influence of these two issues. These sources are complemented through the speeches of Turkish officials to comprehend Turkey's security perception with regards to the civil war. This article argues that the Syrian civil war has caused a threat toward Turkey's security through the attacks of the terrorist groups. However, the article has found that Syrian refugees have not caused any major security issues in Turkey since the beginning of the conflict._The article has four sections. The first section describes the historical background of the Syrian civil war. This section also explains how and when Turkey involved in the civil war. The second section explains the theoretical background of the spillover effect and the issue of refugees. While the spillover effect addresses theoretical foundations of how a conflict spreads neighbouring countries, the issue of refugees explains how migration and refugees can cause a security threat. The third section analyses the effects of the Syrian civil war on Turkey's security. This section also discusses how sub-state armed groups created a security threat since the beginning of the civil war. The last section summarises the main findings of the article. 


\section{Kaynakça / References}

Suriyelilerin karıştığı suç oranı yüzde 1,46'ya düştü. (2018, 22 Ekim). Anadolu Ajansı. 25 Mart 2020 tarihinde https://www.aa.com.tr/tr/turkiye/suriyelilerin-karistigi-suc-orani-yuzde-1-46ya-dustu/1289461 adresinden erişildi.

Acun, C. ve Keskin, B. (2017). The PKK's branch in Northern Syria: PYD-YPG. İstanbul: SETA.

Rebels in southern Syria reach deal to end violence (2018, 20 Ağustos). AlJazeera. 21.08.2018 tarihinde https://www.aljazeera.com/news/2018/07/rebelssouthern-syria-reach-ceasefire-deal-russia-180706130719825.htm.1 adresinden erişildi.

Altun, F. (2018). Hem savaşacak, hem imar edeceğiz. Kriter, 22, 6-8.

Biden Orders Syrian Kurds to Pull Back; Assad Govt Slams Turkish Incursion (2016, 24 Ağustos). ArabNews. 29.10.2016 tarihinde http://www.arabnews.com/node/974651/middle-east adresinden erişildi.

Azam, J.-P. ve Hoeffler, A. (2002). Violence against civilians in civil wars: Looting or terror? Journal of Peace Research, 39(4), 461-485.

Bass, G.J. (2000). Stay the hand of vengeance: The politics of war crimes tribunals (Vol. 142). Princeton, NJ: Princeton University Press.

Syria's Warring Sides Brought Together for Geneva Talks (2017, 23 Şubat). BBC. 24.02.2017 tarihinde https://www.bbc.com/news/world-middle-east39037609 adresinden erişildi.

Brown, M. (1996). The causes and regional dimensions of internal conflict. M. Brown (Der.), The International Dimensions of Internal Conflict içinde (s.571-602). Cambridge, Mass.: MIT Press.

Buhaug, H. ve Gleditsch, K.S. (2008). Contagion or confusion? Why conflicts cluster in space? International Studies Quarterly, 52(2), 215-233

Burton, J.W. (1990a). Conflict: Resolution and provention. London: MacMillan.

Burton, J.W. (1990b). Conflict: Human needs theory. London: Springer.

Carmignani, F. ve Chowdhury, A. (2012). The geographical dimension of the development effects of natural resources. Environmental and Resource Economics, 52(4), 479-498.

U.S. Airstrikes Hit ISIS Targets Inside Syria (2014, 23 Eylül). CNN. 02.10.2014 tarihinde http://edition.cnn.com/2014/09/22/world/meast/u-s-airstrikesisis syria/index.html?hpt=hp_t1 adresinden erişilmiştir. 
Cockburn, P. (2016, 20 Şubat). Turkish threats of intervention after Ankara bombing taken seriously by Obama. 21.02.2016 tarihinde https://www.independent.co.uk/news/world/middle-east/syria-conflict-isis-turkey-barackobama-ankara-bombing-a6886466.html adresinden erişildi.

Collier, P. Elliott, V.L., Hegre, H., Hoeffler, A., Reynal-Querol, M. ve N. Sambanis. (2003). Breaking the conflict trap: Civil war and development policy. Washington, D.C.: World Bank Publications.

Türkiye'deki Suriyeliler Hakkında Neler Biliyoruz? (2019, 31 Temmuz). Cumhuriyet, 25.03.2020 tarihinde http://www.cumhuriyet.com.tr/haber/turkiyedeki-suriyeliler-hakkinda-neler-biliyoruz-1512612 adresinden erişildi.

De Groot, O.J. (2011). Culture, contiguity and conflict: On the measurement of ethnolinguistic effects in spatial spillovers. The Journal of Development Studies, 47(3), 436-454.

Dagher, S. ve Farnaz, F. (2013, 22 Ağustos). Syria presses offensive, shrugs off gas attack claims. 30.01.2018 tarihinde https://www.wsj.com/articles/SB1000142412788732461950457902862115939279 adresinden erişildi.

DNI (2016). ISIL finances: Future scenarios. Washington, D.C.: Office of the Director of National Intelligence.

Ensor, J. (2018). Syrian flag flying over onetime rebel stronghold douma as Russians announce victory in Eastern Ghouta. The Telegraph. 13.04.2018 tarihinde https://www.telegraph.co.uk/news/2018/04/12/syrian-flag-flyingonetime-rebel-stronghold-douma-russians-announce/ adresinden erişildi.

FAC (2018). Kurdish aspirations and the interests of the UK. Londra: Dış İlişkiler Komitesi, Avam Kamarasi.

Galtung, J. (1985). Twenty-five years of peace research: Ten challenges and some responses. Journal of Peace Research, 22(2), 141-158.

Ganguly, S. (1996). Conflict and Crisis in South and Southwest Asia. M. Brown (Der.), The International Dimensions of Internal Conflict içinde (s.141-72). Cambridge, Mass.: MIT Press.

GİGM. (2020, 19 Mart). Y1llara göre geçici koruma kapsamındaki Suriyeliler. T.C. İcişleri Bakanlı̆̆̆ Göç İdaresi Genel Müdürlüğü. 28.03.2020 tarihinde https://www.goc.gov.tr/gecici-koruma5638 adresinden erişildi.

Gurr, T.R. (1980). Handbook of political conflict: Theory and research. New York: Free Press. 
Helm, T. (2014, 2 Ekim). US 'set to launch air strikes' on senior ISIS Terror Chiefs in Syria-World news. The Guardian. 03.11.2015 tarihinde https://www.theguardian.com/world/2014/aug/23/us-air-strikes-isiscommanders-syria-considered adresinden erişildi.

Holliday, J. (2011, 1 Aralık). The struggle for Syria in 2011. Institute for the Study of War. 15.02.2017 tarihinde http://www.understandingwar.org/sites/default/files/Struggle_For_Syria.pdf adresinden erişildi.

Kadıoğlu, İ. A. (2018). Yaşamın sınırını geçmek: Avrupa Birliği Suriyeli sığınmacılar için güvenli bir liman mı?" E.Özensel, G.Bozbaş, F.Kaleci ve M.N. Salur (Der.), Ortadoğu'da Göç Hareketleri ve Değişen Dinamikler içinde (s.4878). Konya: Aybil Yayınları.

Kadıoğlu, İ. A. (2019a). Not our war: Iraq, Iran and Syria's approaches towards the PKK. The Rest: Journal of Politics and Development, 9(1), 44-57.

Kadıoğlu, İ. A. (2019b). The Oslo talks: Revealing the Turkish government's secret negotiations with the PKK. Studies in Conflict E Terrorism, 42(10), 915-933.

Kadıoğlu, İ. A. (2020) Challenges of international negotiations in the Syrian Civil War. Turkish Journal of Middle Eastern Studies 7(1).

Kalyvas, S.N. (2006). The logic of violence in Civil War. Cambridge: Cambridge University Press.

Khan, H.U. ve Khan, W. (2017). Syria: History, the civil war and peace prospects. Journal of Political Studies, 24(2), 587-601.

Lake, D.A. ve Rothchild, D.S. (1998). The international spread of ethnic conflict: Fear, diffusion, and escalation. Princeton, N.J.: Princeton University Press.

Lawson, F.H. (2014). Syria's mutating civil war and its impact on Turkey, Iraq and Iran. International Affairs, 90(6), 1351-1365.

Loescher, G. (1993). Beyond charity: International cooperation and the global refugee crisis: A Twentieth Century fund book. New York: Oxford University Press.

Martin, N. (2018). The AK Party and the Kurds since 2014: A discourse of terror. British Journal of Middle Eastern Studies, 45(4), 543-558.

Millett, R. (2002). Colombia's conflicts: The spillover effects of a wider war (Vol. 57). Dante B. Fascell North-South Center, University of Miami.

Esad ile YPG'den İdlib'de İşbirliği (2020, 16 Şubat). Milliyet. 01.03.2020 tarihinde https://www.milliyet.com.tr/gundem/esad-ile-ypgden-idlibde-is-birligi6145814 adresinden erişildi.

Moore, W.H. ve Shellman, S.M. (2004). Fear of persecution: Forced migration, 1952-1995. Journal of Conflict Resolution, 48(5), 723-745. 
Süleyman Soylu: Suriyeli Kaydına İstanbul Kapalıdır (2019, 6 Temmuz). NTV. 01.02.2020 tarihinde https:/www.ntv.com.tr/turkiye/suleyman-soylusuriyeli-kaydina-istanbul-kapalidir,xNoCL4_zTE6vVk1vJOYPeA adresinden erişildi.

NYT (2014, 9 Ekim). "Obama administration ends Pentagon Program to train Syrian rebels". The New York Times. 09.09.2018 tarihinde https://www.nytimes.com/2015/10/10/world/middleeast/pentagon-program-islamicstate-syria.html?\&hp\&action=click\&pgtype=Homepage\&module=firstcolumn-region\&region=top-news\&WT.nav=top-news adresinden erişildi.

NYT (2015, 12 Ekim). U.S. Weaponry is turning Syria Into proxy war with Russia. New York Times. 26.03.2020 tarihinde https://www.nytimes.com/2015/10/13/world/ middleeast/syria-russia-airstrikes.html adresinden erişildi.

ORSAM (2015). Suriyeli Sığınmacıların Türkiye'ye etkileri. (Rapor No: 195), Ankara: Ortadoğu Stratejik Araştırmalar Merkezi.

Parlar-Dal, E. (2016). Impact of the transnationalization of the Syrian Civil War on Turkey: Conflict spillover cases of ISIS and PYD-YPG/PKK. Cambridge Review of International Affairs, 29(4), 1396-1420.

Iraqi PM Maliki Says Saudi, Qatar openly funding violence in Anbar (2014a, 9 Mart). Reuters. 18.03.2020 tarihinde https://www.reuters.com/article/usiraq-saudi-qatar/iraqi-pm-maliki-says-saudi-qatar-openly-funding-violence-in-anbar-idUSBREA2806S20140309 adresinden erişildi.

German Minister Accuses Qatar of Funding Islamic State Fighters. (2014b, 20 Ağustos). Reuters, 18.03.2020 tarihinde https://www.reuters.com/article/us-iraq-security-germany-qatar/german-minister-accuses-qatar-offunding-islamic-state-fighters-idUSKBN0GK1I720140820 adresinden erişildi.

Syria's Army, Allies Plan Offensive against Insurgents in Aleppo (2015, 14 Ekim). Reuters. 29.11.2015 tarihinde http://uk.reuters.com/article/2015/10/14/ukmideast-crisis-syria-rebels-idUKKCN0S71VO20151014 adresinden erişildi.

Syrian Army, Rebels Agree to 72-Hour Eid Truce, But Fighting Continues (2016, 7 Temmuz). Reuters. 07.09.2016 tarihinde https://www.reuters.com/article/us-mideast-crisis-syria-truce-idUSKCNOZMOPZ adresinden erişildi. 
Putin Declares "Complete Victory" on Both Banks of Euphrates in Syria (2017, 6 Aral1k). Reuters. 16.12.2017 tarihinde https://www.reuters.com/article/usmideastcrisis-syria-putin/putin-declares-complete-victory-on-bothbanks-of-euphrates-in-syria-idUSKBN1E027 adresinden erişildi.

ISIS Economy Based on Illegal Drug Trade-Russian Anti-Drug Chief. (2015, 23 Temmuz). RT, 17.03.2020 tarihinde https://www.rt.com/russia/310571isis-economy-based-on-illegal/ adresinden erişildi.

Salehyan, I. ve Gleditsch, K.S. (2006). Refugees and the spread of Civil War. International organization, 60(2), 335-366.

Salehyan, I. (2007). Transnational rebels: Neighbouring states as sanctuary for rebel groups. World Politics, 59, 217-242.

Salloum, R. (2013, 10 Ekim). From jail to Jihad: Former prisoners fight in Syrian Insurgency. 06.04.2016 tarihinde http://www.spiegel.de/internatio$\mathrm{nal} /$ world/former-prisoners-fight-in-syrian-insurgency-a-927158.html adresinden erişildi.

Shearer, D. (1997). Exploring the limits of consent: Conflict resolution in Sierra Leone. Millennium, 26(3), 845-860.

Skocpol, T. (1979). States and social revolutions: A comparative analysis of France, Russia and China. Cambridge: Cambridge University Press.

Small, M. ve Singer, J.D. (1982). Resort to arms: International and civil wars, 18161980. Beverly Hills, Calif.: Sage Publications, Inc.

Taştan, C., Haklı, S.Z. ve Osmanoğlu, E. (2017). Suriyeli Sığınmacılara dair tehdit algısı: Önyargılar ve gerçekler (Rapor No: 9). Ankara: Polis Akademisi Yayinları.

UNSCSF (1951). United Nations convention relating to the status of refugees. United Nations.

US Treasury (2016). Testimony of assistant secretary Daniel Glaser, U.S. Treasury, before U.S. House Committee on foreign affairs subcommittee on terrorism, nonproliferation, and trade, US Treasury.

van Wilgenburg, W. (2013, 17 January). Kurdish forces clash with main Syrian opposition in Syria, Reports Say. 06.04.2016 tarihinde http://www.rudaw.net/english/news/syria/5666.html adresinden erişildi.

Wallensteen, P. (2018). Understanding conflict resolution. (2nd Edition). London: Sage Publication.

Walter, B.F. (1997). The critical barrier to civil war settlement. International Organization, 51(3), 335-364. 
Weiner, M. (1992). Security, stability, and international migration. International Security, 17(3), 91-126.

Weiner, M. (1996). Bad neighbors, bad neighborhoods: An inquiry into the causes of refugee flows. International Security, 21(1), 5-42.

Woodward, S.L. (2007). Do the root causes of civil war matter? on using knowledge to improve peacebuilding interventions. Journal of Intervention and Statebuilding, 1(2), 143-170.

Yuhas, A. (2016, 17 Eylül). UN security council to hold emergency Meeting on US air Strikes in Syria. The Guardian. 08.10.2016 tarihinde https://www.theguardian.com/world/2016/sep/17/russia-says-us-led-airstrikes-hit-syriantroops-killing-62-and-wounding-dozens adresinden erişildi.

Zapotosky, M. ve Berman, M. (2016, 14 Haziran). Orlando Gunman who pledged loyalty to ISIS was 'homegrown' extremist radicalized online, Obama Says. The Washington Post. 16.03.2020 tarihinde https://www.washingtonpost.com/news/post-nation/wp/2016/06/13/police-orlando-gunmanwas-cool-and-calm-during-hostage-standoff/ adresinden erişildi.

\section{Kaynakça Bilgisi / Citation Information}

Kadıoğlu, A. İ. (2020). Suriye iç savaşı ve Türkiye: Çatışma, güvenlik ve sığınma. OPUS-Uluslararası Toplum Araştırmaları Dergisi, 16(29), 2179-2213. DOI: 10.26466/opus.714551 